Review

\title{
An Up-to-Date Review of Biomaterials Application in Wound Management
}

\author{
Adelina-Gabriela Niculescu ${ }^{1}$ (D) and Alexandru Mihai Grumezescu ${ }^{1,2,3, *(D)}$ \\ 1 Department of Science and Engineering of Oxide Materials and Nanomaterials, \\ Faculty of Applied Chemistry and Materials Science, Politehnica University of Bucharest, \\ 011061 Bucharest, Romania; adelina.niculescu@upb.ro \\ 2 Research Institute of the University of Bucharest-ICUB, University of Bucharest, \\ 050657 Bucharest, Romania \\ 3 Academy of Romanian Scientists, 3 Ilfov Street, 050044 Bucharest, Romania \\ * Correspondence: grumezescu@yahoo.com
}

Citation: Niculescu, A.-G.;

Grumezescu, A.M. An Up-to-Date

Review of Biomaterials Application in Wound Management. Polymers 2022, 14, 421. https://doi.org/ $10.3390 /$ polym 14030421

Academic Editor: Hsiuying Wang

Received: 23 December 2021

Accepted: 17 January 2022

Published: 21 January 2022

Publisher's Note: MDPI stays neutral with regard to jurisdictional claims in published maps and institutional affiliations.

Copyright: (C) 2022 by the authors. Licensee MDPI, Basel, Switzerland. This article is an open access article distributed under the terms and conditions of the Creative Commons Attribution (CC BY) license (https:// creativecommons.org/licenses/by/ $4.0 /)$.

\begin{abstract}
Whether they are caused by trauma, illness, or surgery, wounds may occur throughout anyone's life. Some injuries' complexity and healing difficulty pose important challenges in the medical field, demanding novel approaches in wound management. A highly researched possibility is applying biomaterials in various forms, ranging from thin protective films, foams, and hydrogels to scaffolds and textiles enriched with drugs and nanoparticles. The synergy of biocompatibility and cell proliferative effects of these materials is reflected in a more rapid wound healing rate and improved structural and functional properties of the newly grown tissue. This paper aims to present the biomaterial dressings and scaffolds suitable for wound management application, reviewing the most recent studies in the field.
\end{abstract}

Keywords: biomaterials; wound management; wound dressings; semi-permeable films; foam dressings; hydroactive dressings; hydrocolloids; hydrogels; alginates; biomaterial scaffolds

\section{Introduction}

A wound represents the disintegration in the protective function of the skin, with or without loss of elemental connective tissue, as a result of thermal or physical damage [1,2]. Wound healing is a complicated multiphase and multifactorial physiological process that needs a suitable surrounding to achieve accelerated healing [3,4]. Once an injury occurs, the body starts a cascade of interrelated processes to repair the harmed tissues and restore the integrity of the skin $[5,6]$. Irrespective of what caused the damage, a similar multistep wound healing mechanism, counting hemostasis, inflammation, proliferation, and tissue remodeling stages, is put into action until complete wound closure [7-11] (Figure 1).

On the one hand, acute wounds can heal in a well-timed manner with a successful outcome (anatomic and physiologic restoration of the harmed area). On the other hand, in chronic wounds, the process fails time-wise, leading to incomplete restoration of skin structure and function [12-14]. The number of patients with chronic wounds increases every year [8]. As chronic wounds are only rarely present in otherwise healthy individuals, this phenomenon may be connected to the increase in life expectancy and prevalence of underlying conditions, such as diabetes and obesity [15-17]. As opposed to acute wounds, chronic wounds do not spontaneously heal, posing an aggravating potential that may escalate to amputations or even death $[12,17,18]$. Thus, it is of vital importance to ensure proper wound treatment, focused both on increasing the healing rate and improving the quality of healing [16].

Considering the different types of wounds and advancements in the biomedical field, a broad range of wound management options have appeared as solutions for efficient wound healing [19]. In this respect, this paper describes the wound dressings and biomaterial 
scaffolds developed in recent years, also taking into account the challenges, limitations, and future perspectives in the domain.

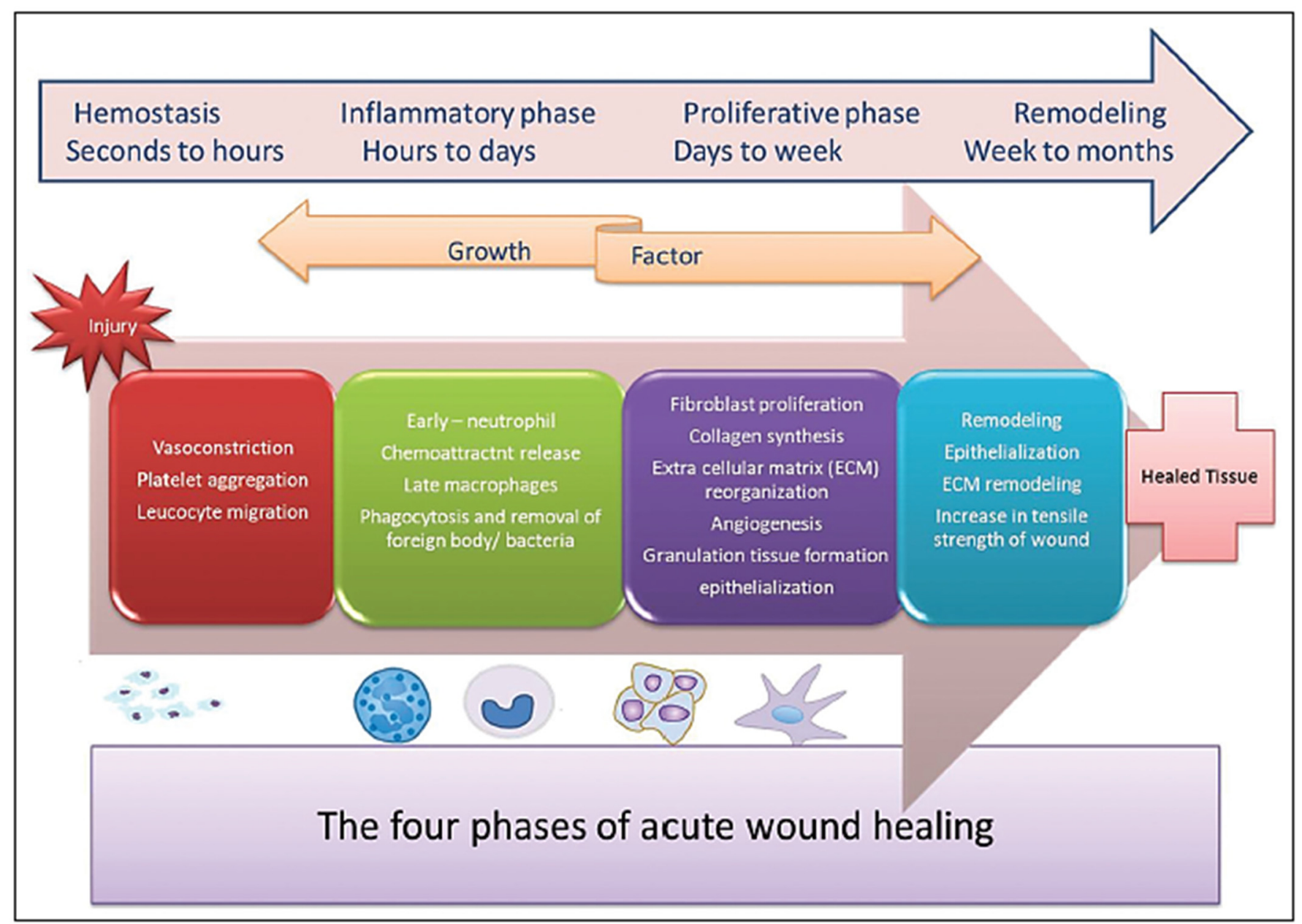

Figure 1. Distinct and overlapping phases of wound healing. Reprinted from an open-access source [20].

\section{Types of Wounds}

A wound can be defined as damage in the skin structure and function caused by external (e.g., physical, mechanical, thermal, chemical, electrical) factors or underlying medical or physiological disorders (e.g., diabetes, malignancies) [21]. Different attributes can characterize a wound, counting blood flow, oxygen, inflammation, edema, infection, wound metabolism, nutrition, innervation, repetitive trauma, previous injury handling, and systemic factors. Further, these characteristics help cumulate knowledge of the origin, pathophysiology, and condition of a wound [22], allowing its classification by several criteria (Figure 2), and permitting the assessment of appropriate treatment.

Among the various classification criteria, the most important one for choosing an adequate dressing and optimal wound management options is considering the healing duration and nature of the restoration process. An acute wound can heal completely, with minimum scar formation, without external support, in a healing time ranging from 8 to 12 weeks depending on the affected anatomical parts, size, and depth of the lesion. However, a chronic wound needs a longer time for healing, may reoccur, and display severe tissue scarring, necessitating specialized care [21]. Table 1 was created to emphasize the differences in the wound healing management of several distinct wounds. 


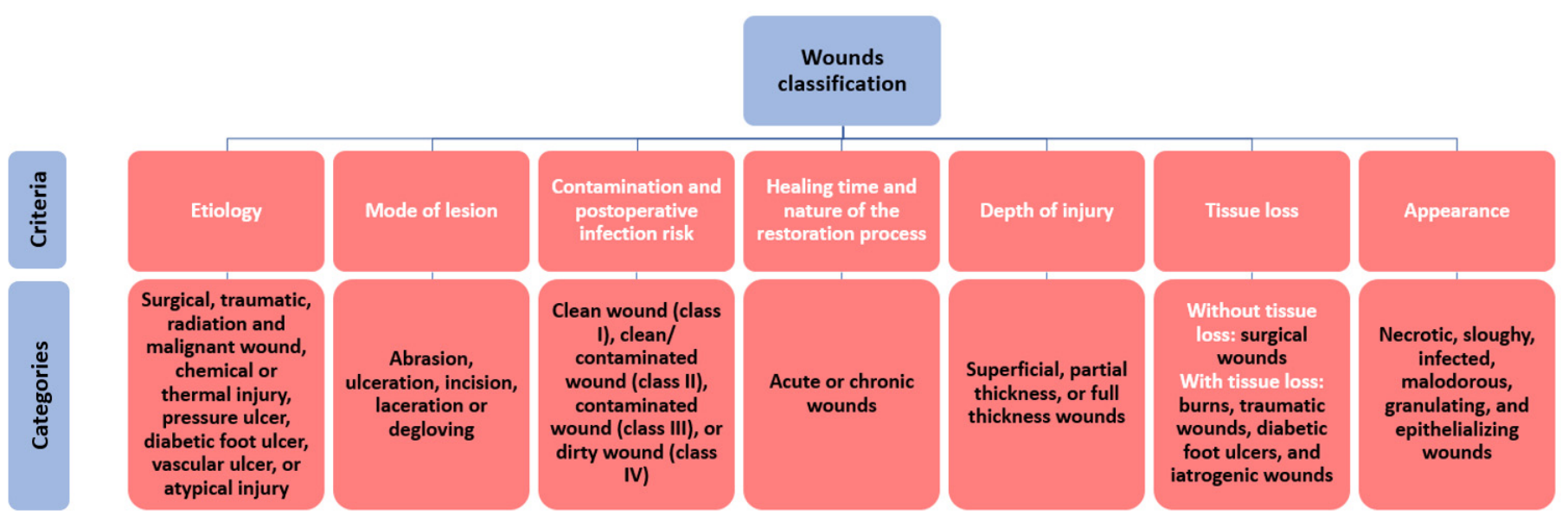

Figure 2. Wound classification. Created based on information from [21].

Table 1. Correlation between various wounds and their appropriate dressing. Adapted from an open-access source [23].

\begin{tabular}{|c|c|c|}
\hline Wound Type & Characterization & $\begin{array}{l}\text { Examples of Appropriate } \\
\text { Types of Dressings }\end{array}$ \\
\hline Diabetic foot ulcer & $\begin{array}{c}\text { Caused by neuropathy and lower extremity vascular disease } \\
\text { Lacks oxygen and blood supply in the wound bed } \\
\text { Long-term stagnation in the inflammatory phase }\end{array}$ & $\begin{array}{l}\text { Silver ion foam dressings, } \\
\text { hydrofiber dressings, } \\
\text { non-adhesive dressings }\end{array}$ \\
\hline Chronic venous leg ulcer & $\begin{array}{c}\text { Caused by the high pressure of the blood in the leg veins } \\
\text { Lacks blood supply in the wound bed } \\
\text { Large amount of necrotic tissue } \\
\text { Abnormal exudate on the ulcer surface } \\
\text { Accompanied by multiple bacterial infections }\end{array}$ & $\begin{array}{l}\text { Alginate dressings, } \\
\text { silver-impregnated dressings, } \\
\text { foam dressings }\end{array}$ \\
\hline Pressure injury & $\begin{array}{c}\text { Caused by stress and tissue tolerance } \\
\text { Local injury to the skin or subcutaneous soft tissue } \\
\text { Occurs at the site of the bone prominence or due to the compression } \\
\text { of a medical device }\end{array}$ & $\begin{array}{l}\text { Foam dressings, hydrocolloid } \\
\text { dressings, polyurethane film }\end{array}$ \\
\hline Radiation dermatitis & $\begin{array}{l}\text { Local skin lesions caused by radiation } \\
\text { Slow cell proliferation } \\
\text { Decreased cytokine activity } \\
\text { Decreased collagen content }\end{array}$ & $\begin{array}{l}\text { Film dressings, } \\
\text { silver-containing hydrofiber, } \\
\text { polyurethane foam, alginate } \\
\text { dressings }\end{array}$ \\
\hline Burn and scald & $\begin{array}{c}\text { Tissue damage caused by heat } \\
\text { Large amount of exudate } \\
\text { Prone to infection } \\
\text { Severe cases can affect subcutaneous and submucosal tissues }\end{array}$ & $\begin{array}{l}\text { Moist occlusive dressings, } \\
\text { silver-impregnated dressings }\end{array}$ \\
\hline
\end{tabular}

\section{Wound Dressings}

Currently, a variety of dressings have been developed and applied in the clinic for treating all sorts of wounds. The benefits of using a wound dressing as a covering for damaged skin include maintaining a moist environment, absorbing excessive extracellular fluid, creating a barrier against infection, maintaining appropriate temperature, ameliorating pain, and cutting health care costs $[3,8,24,25]$.

Depending on their nature of action and temporal character, wound dressings can be classified and characterized, as shown in Figure 3.

Most of the traditional dressings fall under the category of inert dressings (e.g., gauze, cotton pads, bandages), being the least expensive and easiest to manufacture. Nonetheless, they have no antibacterial activity, face challenges in maintaining adequate moisture of the wound bed, and are prone to adhere to newly grown granulation tissue, thus causing pain upon removal. To overcome these drawbacks, research has been directed to developing 
multifunctional wound dressings that can simultaneously ensure the protection of the wounded area against external injuries and pathogens, be comfortable for the patient, reduce pain, increase healing rate, diminish scar formation, reduce care-associated costs, and have an extended shelf-life [3,4,23] (Figure 4).

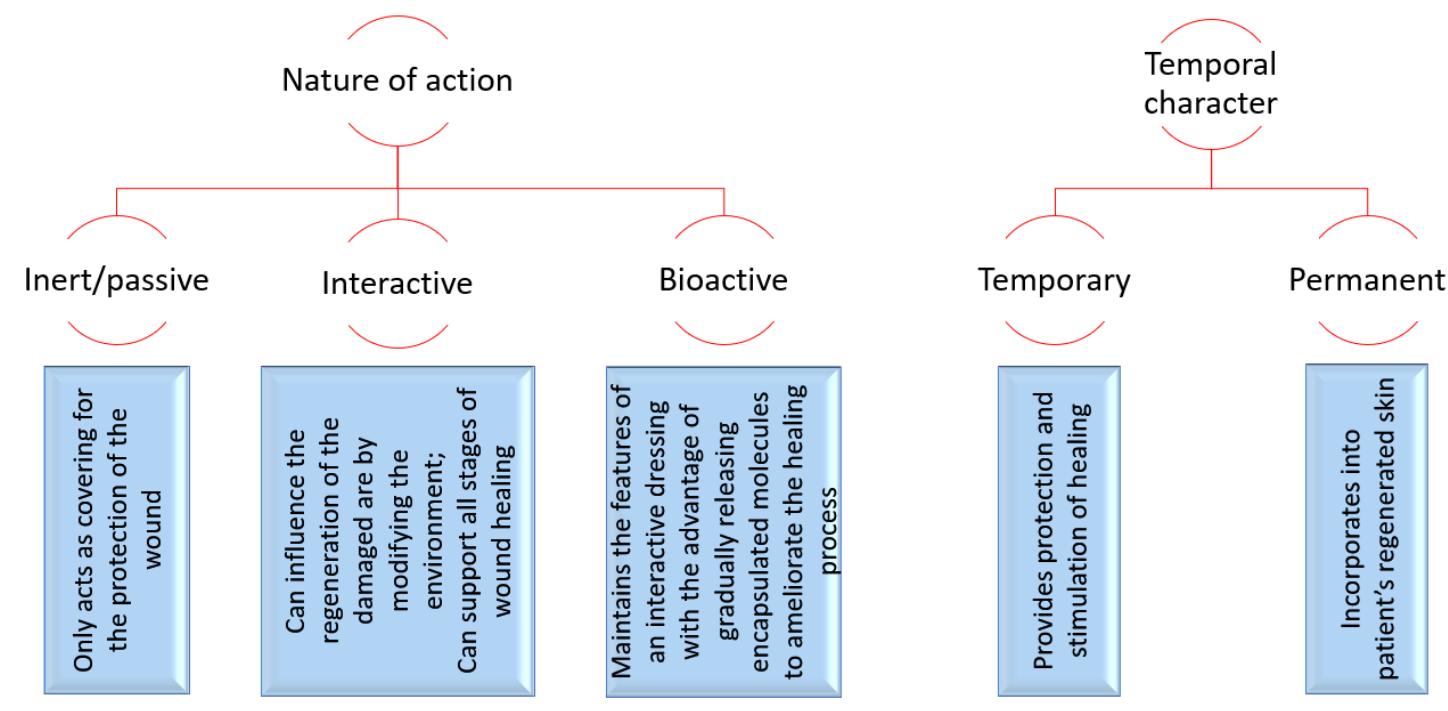

Figure 3. Wound dressing classification. Created based on information from [12,26,27].

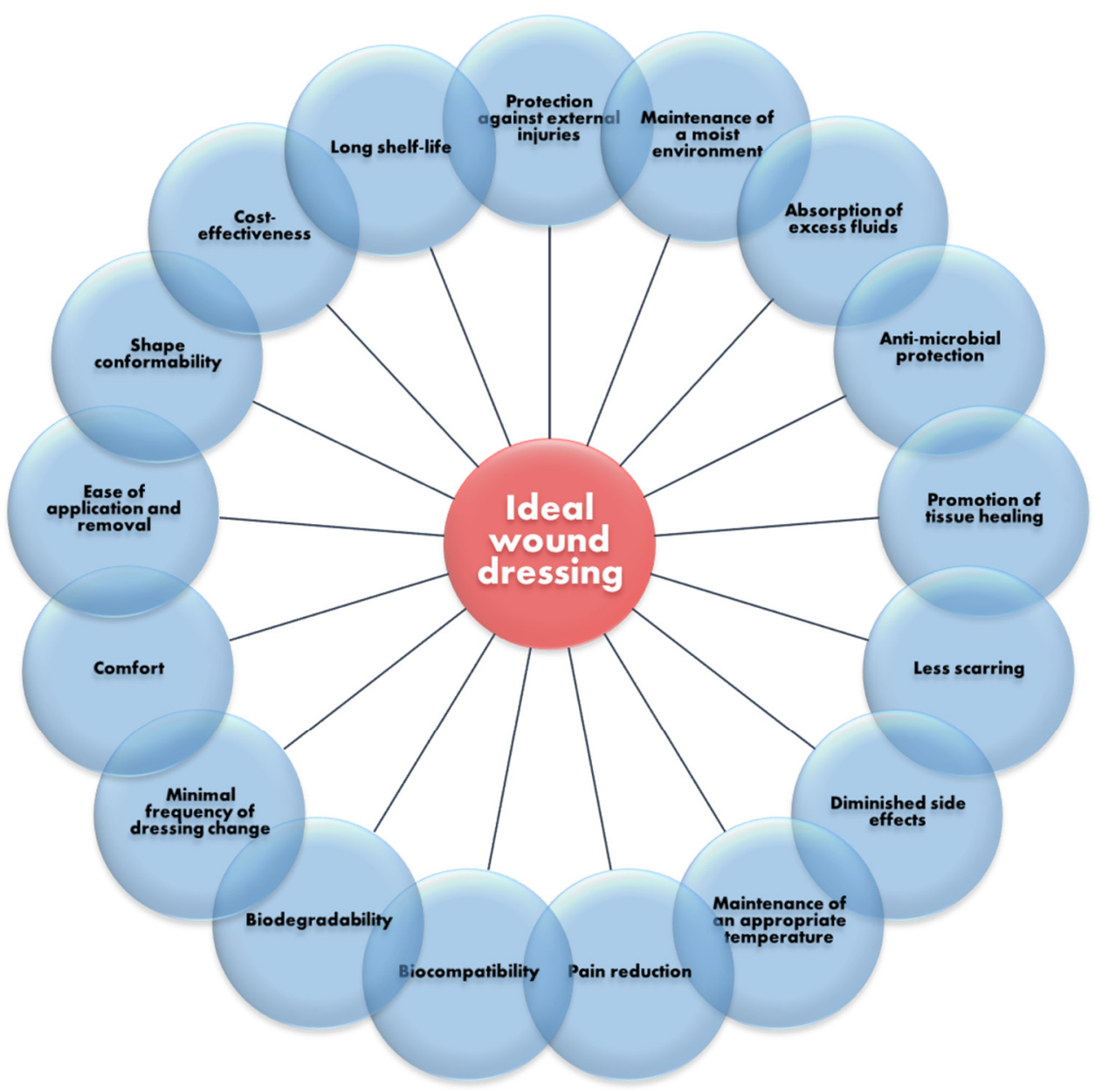

Figure 4. Main properties expected from an ideal modern wound dressing. Created based on information from $[4,23,28]$. 
Attempting to meet as many as possible of these characteristics, research has led to the production of modern wound dressings, such as semi-permeable films, foams, hydroactive dressings, hydrogels, hydrocolloids, alginates, and smart textiles [29,30]. In this respect, the following subsections aim to describe each of the mentioned categories of wound dressings and present their most recent advances.

\subsection{Semi-Permeable Films}

Semi-permeable film dressings are made of adhesive, thin, porous, transparent polyurethane that allows oxygen, carbon dioxide, and aqueous vapor transmission from the wound through the dressing. Concomitantly, these dressings are impermeable to bacteria, providing a barrier to external contamination. Film dressings are also endowed with autolytic debridement properties, suitable for epithelializing wounds and superficial wounds with low exudate amounts. Moreover, the transparency of polyurethane films is advantageous for wound inspection as it can be done without removing the dressing. On the other hand, the main drawbacks of these dressings are represented by their potential traumatic removal and the excessive pooling of exudate when used on heavily exuding wounds $[23,31,32]$.

Several such wound management products have already entered the market, being currently used in the clinic in the treatment of various wounds (Table 2).

Table 2. Examples of commercially available film dressings.

\begin{tabular}{|c|c|c|c|}
\hline Commercial Product & Dressing Type & Observations & Refs. \\
\hline Hydrofilm & $\begin{array}{c}\text { Thin, sterile, semi-permeable film } \\
\text { dressing }\end{array}$ & $\begin{array}{c}\text { Transparent dressing } \\
\text { Waterproof } \\
\text { Bacteria-proof }\end{array}$ & {$[32,33]$} \\
\hline Hyalosafe & Hyaluronic acid-based film & $\begin{array}{c}\text { Transparent dressing } \\
\text { Allows easy wound monitoring } \\
\text { Suitable for treating moderate exuding wounds and } \\
\text { surgery wounds }\end{array}$ & [34] \\
\hline OpSite & $\begin{array}{l}\text { Thin semi-permeable } \\
\text { film dressing }\end{array}$ & $\begin{array}{l}\text { Covered with hypoallergenic acrylic derivatives } \\
\text { More porous and permeable to water vapor and gases, but not } \\
\text { to exudate } \\
\text { Suitable for relatively shallow wounds }\end{array}$ & {$[32,35]$} \\
\hline Tegaderm & $\begin{array}{l}\text { Semi-permeable adhesive } \\
\text { sterile film }\end{array}$ & $\begin{array}{c}\text { Permeable to water vapor and oxygen } \\
\text { Provides a moist environment that enhances healing rate } \\
\text { May be useful in preventing skin breakdown at pressure areas } \\
\text { Suitable for different wounds, including donor sites, minor } \\
\text { burns, abrasions, and lacerations }\end{array}$ & [36] \\
\hline
\end{tabular}

Nonetheless, ongoing research is focused on developing more performant film wound dressing alternatives, employing new biomaterial combinations, and endowing them with enhanced functionalities.

For instance, Rezaei Hosseinabadi et al. [37] have developed polyurethane dressings from two different polyols (i.e., castor oil and CAPA 7201). Both films presented smooth surfaces with no pores or cracks, but the CAPA-based polyurethane had higher crystallinity and lower thermal stability. There was no significant difference between the two formulations in terms of water vapor transmission rate. However, CAPA-based film exhibited higher water absorption capacity than castor oil polyurethane (5.67\% vs. $0.76 \%)$, higher tensile strength (4 vs. $1.7 \mathrm{MPa}$ ), and higher elongation at break (550\% vs. $100 \%)$. Moreover, its lack of toxicity, wound size reduction, and absence of in vivo adverse reactions recommend the CAPA-based polyurethane for use in wound management.

Despite polyurethane, other base materials can be used. For example, Ambrogi et al. [38] have developed alginate films containing pyrogenic silica-supported silver nanoparticles. 
These film dressings showed good hydration properties and a very slow silver release, leading to antimicrobial and antibiofilm activities against common wound-associated bacteria.

Alternatively, Rathore et al. [39] have fabricated biofilms with three different concentrations of chitosan $(1 \%, 1.5 \%$, and $2 \%)$ impregnated with ciprofloxacin to serve as dressings for infection-prone wounds. The dressings presented good texture and biocompatibility, also benefiting from a cost-effective and easy formulation. Moreover, the biomaterial films allowed a sustained drug delivery for wound healing, being effective against Staphylococcus aureus, Escherichia coli, and Pseudomonas aeruginosa, without affecting the NIH 3 T3 fibroblast cell lines. In addition, the films exhibited suitable mechanical properties (tensile strength: $\sim 40 \mathrm{MPa}$; elongation at break: up to $7 \%$ for $2 \%$ chitosan concentration; swelling: up to $290 \pm 10 \%$ for $2 \%$ chitosan concentration) for wound dressing applications.

Different antimicrobial dressings were designed by Hubner et al. [40], who have prepared gelatin-based films containing different concentrations of glycerol and clinoptilolite zeolite impregnated with silver ions. The best results were obtained for $25 \%$ glycerol concentration and $0.5 \%$ zeolite concentration, leading to the slow release of the active compound and suitable physicochemical properties (tensile strength: $1.02 \pm 0.05 \mathrm{MPa}$, elongation at break: $295 \pm 19 \%$, moisture content: $23.6 \pm 0.2 \%$ ) for the desired application. The researchers also obtained satisfactory bactericidal activity against E. coli and S. aureus, concluding that these films could serve as promising wound dressings that can ensure long-term antibacterial protection.

Another study by Akhavan-Kharazian et al. [41] proposed the improvement of mechanical properties of chitosan and gelatin film dressings by the incorporation of nanocrystalline cellulose (NCC) and calcium peroxide (CP) particles. The addition of these materials was also seen to reduce the water vapor transmission rate and swelling of the samples, while $\mathrm{CP}$, in particular, was reported to increase the antibacterial activity of the dressings. Furthermore, the MTT assay results showed an increase in the growth of human fibroblast cells, demonstrating the biocompatibility and healing capacity of the newly developed dressings.

\subsection{Foams}

Foam dressings are solid porous matrices mainly made from polyurethane that can also be coated with a layer of soft silicone [32]. Foams can be sterilized and administered to wounds without causing any discomfort to the patient [42]. Polyurethane is particularly advantageous for wound dressings due to its softness, flexibility, optimal mechanical characteristics, air permeability, excellent absorption capability, and cost-effectiveness [43-45]. Moreover, the addition of a silicone membrane ensures exudate passage into the insulating foam, allows the dressing to remain in place, and protects the area from trauma when removing the dressing [32]. However, if factors, such as thickness, density, tensile strength, and elongation, of the freeze-dried foam are not adequately tuned, foams can produce discomfort and maceration of skin around the wound periphery. Another possible drawback of foams is the ingrowth of newly formed tissue into the dressing due to infrequent changes, leading to shearing trauma upon dressing removal [32,42].

Several foam dressings products that are already available on the market have been gathered in Table 3.

In addition to the commercially available products, recent research continues to design and investigate other foam-based wound dressings in the effort to create better wound management options.

In this respect, Namviriyachote et al. [43] have combined polyurethane foam dressings with different biomacromolecules, asiaticoside, and silver nanoparticles. At $2 \%$ incorporation, natural polymers (i.e., starches, high molecular weight chitosan, gelatin, and carboxymethyl cellulose) were able to improve the physicochemical and mechanical properties of the foam. Specifically, the first three biomacromolecules provided a stiffer and more porous structure, while carboxymethylcellulose exhibited the highest compression strength $\left(15.29 \pm 2.72 \times 10^{-3} \mathrm{MPa}\right)$ but reduced water vapor transmission capacity $\left(0.76 \pm 0.28 \mathrm{~g} / \mathrm{m}^{2} / \mathrm{min}\right)$. 
Table 3. Examples of commercially available foam dressings.

\begin{tabular}{|c|c|c|c|}
\hline Commercial Product & Dressing Type & Observations & Refs. \\
\hline Allevyn & Hydrocellular foam dressing & $\begin{array}{c}\text { Able to absorb, retain, and transpire to achieve optimal fluid balance } \\
\text { Promotes faster healing by maintaining an optimal environment } \\
\text { Reduces maceration risk by not allowing the wounded area to become } \\
\text { too wet } \\
\text { Common choice for managing donor site wounds }\end{array}$ & {$[32,46,47]$} \\
\hline Betafoam & Povidone-iodine foam dressing & $\begin{array}{c}\text { Effective antimicrobial activity with minimal cytotoxicity to host cells } \\
\text { Better ease of use, less bleeding, and adherence on removal of dressing, less } \\
\text { leakage of exudate compared to commonly used dressings } \\
\text { Superior fluid-handling capacity (e.g., improved moisture retention, fast } \\
\text { fluid absorption time) } \\
\text { Better wound-healing efficacy than conventional mesh dressings }\end{array}$ & {$[46,48]$} \\
\hline Cavi-care & Foam dressing & $\begin{array}{c}\text { The porous structure allows the maintenance of a moist environment to } \\
\text { promote healing, while permitting excessive exudate to be drained through } \\
\text { the dressing } \\
\text { Helps avoid secondary infection and offensive smell } \\
\text { Suitable for cavity wounds, auricular pressure wounds, and following } \\
\text { primary non-glandular hypospadias repair or syndactyly correction }\end{array}$ & {$[32,49]$} \\
\hline Mepilex & Silver-impregnated foam dressing & $\begin{array}{c}\text { Excellent antimicrobial activity against common wound pathogens } \\
\text { Absorbs exudate and maintains a moist wound environment } \\
\text { Self-adherence properties can cut treatment costs by reducing the need for } \\
\text { frequent dressing change } \\
\text { Suitable for a variety of wounds, including surgical wounds, pressure } \\
\text { injuries, and burns }\end{array}$ & {$[32,50-52]$} \\
\hline Permafoam & Foam dressing & $\begin{array}{c}\text { Has a gas permeable, waterproof, and germ-resistant outer layer } \\
\text { Absorbs exudate to create a moist environment } \\
\text { Painless on removal } \\
\text { Leaves no residue } \\
\text { Suitable for moderate to high exuding wounds } \\
\text { May be used as a secondary dressing }\end{array}$ & {$[32,36]$} \\
\hline
\end{tabular}

Alternatively, Pahlevanneshan et al. [53] have developed a porous nanocomposite polyurethane-nanolignin foam coated with ethanol extract of propolis (EEP). The addition of nanolignin and EEP increased the mechanical strength (tensile strength: $0.82 \pm 0.09 \mathrm{MPa}$ ) and hydrophilicity (water contact angle: $50.1 \pm 2.1^{\circ}$ ) of the dressing. Moreover, EEP endowed the foam with antibacterial properties. Overall, the dressing exhibited high cell viability and cell adhesion, promoting better skin wound healing than polyurethane alone.

Another example of an advanced polyurethane-based foam is offered by Bužarovska et al. [54]. The researchers employed soft thermoplastic polyurethane and zinc oxide to create highly porous nanocomposite foams. The foam dressing samples showed a low cytotoxic potential, good biocompatibility, adequate water vapor transmission $\left(\sim 8.0-8.9 \mathrm{mg} / \mathrm{cm}^{2} / \mathrm{h}\right)$, and the ability to support cell growth. Furthermore, the nanocomposite foams exhibited significant activity against Gram-positive and Gram-negative bacteria, being suitable candidates for active wound dressings.

Antibacterial foam dressings were also obtained by dos Santos et al. [55], who have deposited usnic acid-doped polyaniline on polyurethane foam. The scientists obtained strong antibacterial and antibiofilm ( $>90 \%$ reduction in biofilm adhesion degree) properties against $E$. coli and $S$. aureus, while the dressing also maintained its flexibility and intrinsic porosity. In addition to its efficiency, the material is also low-cost and eco-friendly, being a promising prototype for wound dressings.

Interesting results were also reported from the investigation of foams based on other biomaterials. For instance, Dutta et al. [56] propose using a topical hemostatic patch, called VELSEAL-T, at the bleeding wounded site of hemophilia patients. The proposed material is a chitosan-gelatin foam whose hydrophilic properties and porous structure facilitate large amounts of fluid absorption. Thus, blood is trapped inside the porous space of the foam where it comes in contact with thrombin and calcium chloride incorporated in the patch, facilitating clotting. By supplementary incorporation of tranexamic acid into the dressing, clot formation is reinforced, leading to rapid cessation of bleeding.

\subsection{Hydroactive Dressings}

Hydroactive dressings are multilayered polymer dressings that are based on a moist principle. They are similar to foams but absorb exudate in a different manner; they draw fluid into the polymer's structure and trap the exudate to maintain a moist wound environ- 
ment. This phenomenon is highly useful in preventing wound drying, promoting wound healing, and reducing the risk of maceration. Moreover, hydroactive dressings do not stick to the wound bed, thus lowering patient trauma on dressing removal, soothing painful wounds, and ensuring patient comfort and tolerability. In what concerns their limitations, hydroactive wounds are not recommended for lightly exuding and dry wounds [32,57].

Hydroactive dressings have shown promising results in the clinic, commercially available products being particularly effective in managing chronic wounds [57] (Table 4).

Table 4. Examples of commercially available hydroactive dressings.

\begin{tabular}{|c|c|c|c|}
\hline Commercial Product & Dressing Type & Observations & Refs. \\
\hline Biatain Ag & $\begin{array}{l}\text { Hydroactive silver-impregnated } \\
\text { foam-like dressing }\end{array}$ & $\begin{array}{l}\text { Soft, absorbent dressing } \\
\text { Exerts antimicrobial activity due to incorporated silver } \\
\text { Superior performance than its non-silver counterpart in terms } \\
\text { of relative ulcer area reduction and healing rate } \\
\text { Can be used in the treatment of hard-to-heal venous leg ulcers }\end{array}$ & {$[32,58-60]$} \\
\hline Cutinova Hydro & Hydroactive foam-like dressing & $\begin{array}{c}\text { Self-adhesive polyurethane gel matrix embedded with highly } \\
\text { absorptive granules } \\
\text { Allows a fluid uptake of } 10 \text { times its weight } \\
\text { Allows the loss of water vapor from the dressing and } \\
\text { transmission of oxygen through it to the wounded area } \\
\text { Effective in debriding slough and necrotic tissue } \\
\text { Can be used in the treatment of leg ulcers, pressure ulcers, } \\
\text { traumatic wounds, and diabetic foot ulcers }\end{array}$ & {$[32,61]$} \\
\hline Tielle & Hydroactive foam-like dressing & $\begin{array}{c}\text { Has additional wound contact layers to avoid adherence when } \\
\text { the wound is dry } \\
\text { The occlusive polymeric backing layer prevents excess fluid } \\
\text { loss and bacterial contamination } \\
\text { Can be used on venous leg ulcers, pressure ulcers, and other } \\
\text { similar wounds } \\
\text { Can act both as a primary and secondary dressing }\end{array}$ & {$[32,35,62]$} \\
\hline
\end{tabular}

More recent research in the field of hydroactive dressings is not only focused on improving their properties but also on extending their applications to other types of wounds.

For instance, Yang et al. have investigated the use of a hydroactive dressing (i.e., DermaPlast Hydro \#5353672) on the nasal ala of patients who underwent orthognathic surgery. Employing the hydroactive dressings for treating these wounds was seen to reduce the incidence of pressure injuries compared to adhesive tape, which was the standard of care in the control group. Nonetheless, the researchers suggested that additional studies are needed to confirm these results, recommending the conduction of a multisite randomized controlled trial to compare this dressing with other prevention methods.

One more example is offered by Ioffe et al. [63], who have evaluated the efficiency of a hydroactive dressing (i.e., HydroClean Plus) in the treatment of diabetic foot syndrome, particularly in patients with purulent-necrotic complications. The researchers reported an enhance in wound healing rate, achieving a complete cleaning of the affected area 6-7 days earlier than in the control group. The observation was confirmed by the results of cytological examination of the smears, leading to the conclusion that the used hydroactive dressing may be the optimal choice in managing this category of patients.

\subsection{Hydrocolloids}

Hydrocolloids are interactive occlusive, moisture-retentive dressings composed of two layers: a suspension of hydrophilic colloidal particles and a polyurethane layer that is impermeable to bacteria. Hydrocolloid dressings contain gel-forming agents (e.g., gelatin, sodium carboxymethylcellulose, and pectin) and other materials, such as elastomers and adhesive coatings. Thus, in the presence of wound exudate, this type of dressings forms a gel phase that enables moisturizing the wound and protecting the newly formed granulation tissue [31,32]. Other important advantages of hydrocolloids include pain-free removal, barrier properties against water, oxygen, or bacteria, and the promotion of angiogenesis and granulation [32]. 
Due to their beneficial properties for wound healing, several hydrocolloids entered the market and clinical facilities, showing good results in treating various wound types (Table 5).

Table 5. Examples of commercially available hydrocolloid dressings.

\begin{tabular}{|c|c|c|c|}
\hline Commercial Product & Dressing Type & Observations & Refs. \\
\hline Comfeel & Hydrocolloid dressing & $\begin{array}{c}\text { Promotes healing and reduces patients' discomfort } \\
\text { Absorbs at least two times its own weight } \\
\text { Can be used for various wounds, including severe friction } \\
\text { burns, gravel rash, and following excision of pilonidal sinuses }\end{array}$ & {$[64,65]$} \\
\hline DuoDerm & Hydrocolloid dressing & $\begin{array}{c}\text { Occlusive dressing, impermeable to water, water vapor, } \\
\text { oxygen, and bacteria } \\
\text { Provides pain relief by keeping the nerve endings moist } \\
\text { The moist environment promotes debridement of sloughy } \\
\text { tissue and facilitates granulation } \\
\text { Patients can bathe with the dressing in situ } \\
\text { Helps prevent skin breakdown at pressure areas } \\
\text { Suitable for superficial wounds with light to moderate exuding }\end{array}$ & [36] \\
\hline Granuflex & Hydrocolloid dressing & $\begin{array}{c}\text { Occlusive dressing, impermeable to water, water vapor, } \\
\text { oxygen, and bacteria } \\
\text { Provides pain relief by keeping the nerve endings moist } \\
\text { The moist environment promotes debridement of sloughy } \\
\text { tissue and facilitates granulation } \\
\text { Patients can bathe with the dressing in situ } \\
\text { Suitable for light to moderate exuding wounds } \\
\text { Can be applied to partial or full thickness wounds }\end{array}$ & [36] \\
\hline OxyBand & $\begin{array}{l}\text { Self-contained multiple layers } \\
\text { hydrocolloid dressing }\end{array}$ & $\begin{array}{l}\text { Oxygen prefilled wound dressing } \\
\text { The top layer has a waterproof barrier film } \\
\text { Provides superior pressure redistribution and significantly } \\
\text { reduced peak pressure compared with standard foam and } \\
\text { silicone dressings }\end{array}$ & {$[58,66]$} \\
\hline
\end{tabular}

Furthermore, research continued in the field, focusing on the development of more advanced hydrocolloid dressings, which involve new biomaterial combinations, provide enhanced functionalities, and allow synergistic treatment results when used together with other methods.

For instance, Wojcik et al. [67] have developed superabsorbent curdlan-based dressings acting as typical hydrocolloids. The authors used this natural polymer in combination with agarose and chitosan to create hybrid biomaterials suitable for the management of highly exuding wounds. The foam-like materials with a highly porous structure (66-77\%) transformed into a soft gel in contact with the wounded area, exhibiting superabsorbent ability ( $1 \mathrm{~g}$ of biomaterial absorbs $\sim 15 \mathrm{~mL}$ of exudate) and a proper water vapor transmission rate (1700-1800 g/ $\mathrm{m}^{2} /$ day) for optimal wound healing. The as-described dressings are non-toxic, stable in the presence of collagenases, biodegradable in lysozyme solution, and hinder fibroblast attachment. Taking into account the characteristics of the newly developed materials, the researcher concluded that they are promising dressing in the management of chronic wounds with moderate to high exudate.

A different wound management strategy was employed by Collado-Boira et al. [68], who have used sodium carboxymethylcellulose cellulose fibers (SCCFs) in combination with an extra thin hydrocolloid adhesive dressing in patients with peristomal skin lesions caused by severe irritant contact dermatitis. The as-described protocol showed promising results, reducing discomfort after 7 days and ensuring wound healing within 4 weeks.

Another synergistic approach is proposed for treating varicose ulcer wounds in patients with diabetes. According to Tănăsescu [69], by combined use of targeted antibiotic therapy, systemic treatment, local surgical treatment, and application of a hydrocolloid dressing, very good results can be obtained in a much shorter time than for conventional therapy. Moreover, colloidal-absorbent therapy is accessible through the polyclinic service or even at home. 


\subsection{Hydrogels}

Hydrogels are complex three-dimensional structures composed of hydrophilic waterinsoluble polymers that can absorb high water volumes (from 10\% to thousands of times their equivalent weight). Thus, hydrogels present an excellent moisturizing ability and play a significant role in cleansing necrotic tissue. Moreover, hydrogels are generally transparent, offering the possibility for easy wound monitoring. Hence, hydrogel dressings can be employed in the treatment of various wounds, including burns, surgical wounds, pressure ulcers, and radiation dermatitis $[23,32,70]$. Unlike other modern wound dressings (e.g., foams, films, hydrocolloids), hydrogels also exhibit positive degradation properties, which permit the use of these materials as carriers when a targeted delivery of bioactive substances is required to the wound [31].

To emphasize their variety and versatility, a selection of commercially available hydrogels for wound management is presented in Table 6.

Table 6. Examples of commercially available hydrogels.

\begin{tabular}{|c|c|c|c|}
\hline Commercial Product & Dressing Type & Observations & Refs. \\
\hline Activheal Hydrogel & Amorphous hydrogel & $\begin{array}{c}\text { Helps soften and hydrate eschar } \\
\text { Provides a moist environment that facilitates healing } \\
\text { Effective in the debridement of necrotic, dry, or sloughy wounds } \\
\text { Suitable for light to medium exuding wounds } \\
\text { Can remain in situ for up to three days } \\
\text { Can be applied to varying depths of wounds } \\
\text { Requires a secondary dressing to hold it in place }\end{array}$ & {$[36,62]$} \\
\hline AquaClear & Sheet hydrogel & $\begin{array}{c}\text { Active moisture-release system } \\
\text { Maintains an optimal moisture balance that aids in healing } \\
\text { Promotes re-epithelialization } \\
\text { Occludes the wound without the need for a secondary dressing } \\
\text { Suitable for various ulcers, burns, and traumatic wounds }\end{array}$ & {$[29,62,71]$} \\
\hline Flaminal & Antimicrobial hydrogel & $\begin{array}{c}\text { Embedded with an enzyme system that forms free radicals that kill bacteria by } \\
\text { destroying their cell wall } \\
\text { Wound exudate is absorbed in the hydrated form of the dressing } \\
\text { Ensures continuous debridement of dry scab and necrotic tissues } \\
\text { Suitable for burn wounds }\end{array}$ & {$[32,72]$} \\
\hline Hydrosorb & Sheet hydrogel & $\begin{array}{l}\text { Suitable for keeping granulation tissue and young epithelium moist } \\
\text { Provides a cushioning effect for wound protection } \\
\text { Soothing and cooling effect on superficial burns } \\
\text { Occludes the wound without the need for a secondary dressing }\end{array}$ & {$[32,62,73]$} \\
\hline HydroTac & Sheet hydrogel & $\begin{array}{c}\text { Actively releases moisture and increases growth factor concentration } \\
\text { Stimulates epithelial wound closure } \\
\text { Has an air-permeable, waterproof, and bacteria-proof film backing } \\
\text { Effective in removing devitalized tissue } \\
\text { Occludes the wound without the need for a secondary dressing }\end{array}$ & {$[32,62,74]$} \\
\hline IntraSite & Thick sterile hydrogel & $\begin{array}{c}\text { Moderate elastic properties } \\
\text { Improved patient comfort } \\
\text { Adequately rehydrates devitalized tissue } \\
\text { Promotes autolytic debridement in necrotic or sloughy wounds } \\
\text { Can be used on infected wounds due to its bacteriostatic and fungistatic activity } \\
\text { Easy application on the wounded area } \\
\text { Suitable for leg ulcers, pressure ulcers, and surgical wounds }\end{array}$ & {$[32,62,75]$} \\
\hline Iodozyme & Two-layer hydrogel & $\begin{array}{l}\text { Exerts antimicrobial activity through iodine release } \\
\text { Suitable for patients with chronic infection or bacterial bioburden }\end{array}$ & {$[32,58,76]$} \\
\hline Oxyzyme & Two-layer hydrogel & $\begin{array}{l}\text { Provides enzyme-activated in situ oxygen production } \\
\text { Impedes microbial growth through iodine release } \\
\text { Suitable for treating chronic wounds }\end{array}$ & {$[32,58,76]$} \\
\hline Solosite & $\begin{array}{l}\text { Amorphous thin } \\
\text { preserved hydrogel }\end{array}$ & $\begin{array}{c}\text { Can be applied to fill a deep wound with irregular contours } \\
\text { Suitable for low to moderately exuding wounds } \\
\text { Can be used for treating pressure injuries, sinuses, and cavity wounds }\end{array}$ & {$[32,76]$} \\
\hline
\end{tabular}

Regarding their disadvantages, the main drawback of plain hydrogels is the poor bacterial barrier properties [32]. Thus, recent research was directed towards improving their antimicrobial activity by incorporating different nanomaterials into the dressings [44].

For instance, silver nanoparticles (Ag NPs) were the antimicrobial agent of choice for Nešović et al. [77], who have embedded them into chitosan and polyvinyl alcohol hydrogels. The resulting nanocomposite dressings presented excellent physicochemical properties, appropriate swelling and silver release profiles, and strong antibacterial activity against E. coli and S. aureus. Similarly, Diniz et al. [78] have incorporated Ag NPs into sodium alginate/gelatin hydrogels for healing cutaneous lesions. The authors reported promising in vivo results, counting the ability of the dressing to reduce wound size, promote earlier 
development and maturation of granulation tissues, and significant bactericidal activity against $P$. aeruginosa and S. aureus. Ag NPs were also used by Gupta et al. [79]. The researchers prepared Ag NPs using curcumin-cyclodextrins loaded into bacterial cellulosebased hydrogels, obtaining high cytocompatibility, moist wound-healing properties, and potent antimicrobial activity against common wound-infecting pathogens.

Another strategy approached in recent studies consists of zinc oxide nanoparticle (ZnO NPs) addition. For example, Khorasani et al. [80] have loaded ZnO NPs into heparinized polyvinyl alcohol/chitosan hydrogels. ZnO NPs addition was noted to improve the mechanical and thermal properties of the hydrogel dressing, ensure the sustained release of heparin, and endow the material with antibacterial properties. Alternatively, Raafat et al. [81] have embedded ZnO NPs into a xanthan/polyvinyl alcohol-based wound dressing hydrogel. The as-prepared material showed a homogenous porous structure that, which, along with the presence of $\mathrm{ZnO}$ NPs, contributes to the control of fluid uptake ability, water retention, and water vapor transmission rate. Moreover, the nanocomposite hydrogel displayed an efficient microbial barrier potency, with strong activity against S. aureus, E. coli, and C. albicans.

An innovative hydrogel dressing was proposed by Kudinov et al. [82], who fabricated an easy-to-use placental mesenchymal stromal cell (MMSC) secretome-based chitosan hydrogel for the treatment of $S$. aureus-infected burn wounds. After testing this novel dressing, the researchers reported almost complete epithelialization, with high levels of vascularization and angiogenesis. MMSC secretome was found to have a similar antimicrobial activity to that of Miramistin and Bepanthen Plus, and the ability to secrete factors that can promote skin healing in all regeneration phases. Thus, the authors recommend the translation of this hydrogel into clinical practice as its preparation is rapid and simple. However, the obtained experimental data requires further research and clarification before moving to human use.

\subsection{Alginates}

Alginates (i.e., calcium or calcium sodium salts of alginic acid) are naturally occurring polymers that have been separated in the literature into a distinct category of dressings [83]. When applied to a wound, they form a hydrophilic sodium alginate gel as the calcium present in the material's structure reacts with the sodium salts present in the wounded area. The formed gel further absorbs the fluid at the injury site, providing a moist environment for the wound to heal optimally $[23,32,44,84-86]$. Other advantages of alginate dressings include their easy removal, hemostatic properties, flexibility, permeability to water vapor, carbon dioxide, and oxygen, and protection against bacterial infections. On the other hand, several drawbacks must be taken into consideration when using alginates for wound management. Specifically, alginates are non-adhesive, and they may provoke allergic reactions in individuals allergic to seaweed-derived products or when the exudate amount is not enough for forming the removable gel $[32,42,87]$.

Nonetheless, these disadvantages can be overcome or avoided in practice by matching the dressing to suitable types of wounds and adding a secondary dressing to hold it in place. Thus, several alginate products have already entered the market and have been used in the clinic with good results (Table 7).

In addition to the commercially available products, ongoing research focuses on designing enhanced alginate dressing formulations, considering the advantageous properties that emerge at the convergence of this natural polymer with other biomaterials, nanoparticles, and/or biomolecules. 
Table 7. Examples of commercially available alginate dressings.

\begin{tabular}{|c|c|c|c|}
\hline Commercial Product & Dressing Type & Observations & Refs. \\
\hline Algiderm & $\begin{array}{c}\text { Guluronic acid-rich alginate } \\
\text { dressing }\end{array}$ & $\begin{array}{c}\text { Induces a strong gel formation } \\
\text { Excellent dressing integrity } \\
\text { Can absorb } 20 \text { times its weight in exudate }\end{array}$ & [88] \\
\hline Curasorb & $\begin{array}{l}\text { Guluronic acid-rich calcium } \\
\text { alginate dressing }\end{array}$ & $\begin{array}{l}\text { Needled non-woven structure } \\
\text { Induces a strong gel formation } \\
\text { Excellent dressing integrity }\end{array}$ & {$[88,89]$} \\
\hline Kaltostat & $\begin{array}{l}\text { Guluronic acid-rich calcium } \\
\text { alginate dressing }\end{array}$ & $\begin{array}{c}\text { Forms a firm hydrophilic gel over the wound, ensuring a moist warm } \\
\text { environment } \\
\text { May be applied to bleeding wounds due to its hemostatic properties } \\
\text { Suitable for moderate to high exuding wounds } \\
\text { Can be used also for infected wounds, but necessitates more frequent change } \\
\text { Requires a secondary dressing to hold it in place }\end{array}$ & {$[35,36]$} \\
\hline Seasorb & $\begin{array}{l}\text { Mannuronate-rich } \\
\text { alginate dressing }\end{array}$ & $\begin{array}{c}\text { Forms a soft flexible gel upon hydration } \\
\text { Limits wound secretions } \\
\text { Minimizes bacterial contamination } \\
\text { Suitable for burns, donor sites, diabetic, leg, and pressure ulcers }\end{array}$ & {$[32,35,84,88]$} \\
\hline Sorbsan & $\begin{array}{l}\text { Mannuronate-rich calcium } \\
\text { alginate dressing }\end{array}$ & $\begin{array}{c}\text { Unneedled pressure-rolled structure } \\
\text { Forms a soft fragile gel } \\
\text { Disintegrates rapidly compared with other alginates } \\
\text { Significant beneficial effects on leg ulcers } \\
\text { Can be used on burns, donor sites, pressure ulcers. and surgical wounds }\end{array}$ & {$[32,35,88,89]$} \\
\hline Tegagel & $\begin{array}{l}\text { Mannuronate-rich calcium } \\
\text { alginate dressing }\end{array}$ & $\begin{array}{c}\text { Hydroentangled nonwoven structure } \\
\text { As the fibers are closely compressed, fluid diffusion is more difficult than in } \\
\text { other alginates } \\
\text { High degree of wet integrity }\end{array}$ & [89] \\
\hline
\end{tabular}

As an example, Zhao et al. [90] have coated a calcium alginate dressing with a mixture of high and low-molecular-weight chitosan. After testing the alginate-based samples, the researchers noted good moisturizing and antibacterial properties, inhibition of inflammation, promotion of wound healing, and non-cytotoxicity.

An interesting strategy for treating diabetic foot ulcers (DFU) via alginate-based dressings is proposed by Wang et al. [91]. The scientists created an alginate wound dressing containing magnesium and hydroxypropyltrimethyl ammonium chloride chitosan, which presented good prospects for clinical translation. Specifically, the dressing showed good biocompatibility, accelerated DFU healing, and effectively eradicated antibiotic-resistant bacteria, such as methicillin-resistant $S$. aureus and methicillin-resistant $S$. epidermidis.

A different approach was taken by Liang et al. [92], who have fabricated an oxidized sodium alginate sponge functionalized with polydopamine/silver composite nanospheres. The functionalization contributed to improving the stability of the sponge without compromising its porosity. Moreover, the as-described dressing exhibited high blood compatibility, low cell cytotoxicity, good hemostatic performance, and strong antimicrobial activity against $P$. aeruginosa, S. aureus, and E. coli.

Alternatively, Azam et al. [93] have developed a novel alginate-based material by adding 2-deoxy-D-ribose to clinically used alginates. The dressings showed more than $90 \%$ release of the sugar in the first three days, followed by a lesser and sustained release for up to eight days. Moreover, sugar addition was observed to significantly increase wound healing rate when compared to both the control group and the group treated with pristine alginate.

\subsection{Smart Textiles}

For decades, people have been using textile wound dressings as protectors against pathogens and external injuries. Nonetheless, improving these materials and creating advanced wound management options is still of great interest nowadays [94-97].

In the context of designing smart textiles, electrospun nanofibers have drawn tremendous scientific attention, especially due to the possibility of loading bioactive molecules within the nanofiber [98-100]. Thus, optimal burst control and enhanced drug stability can be achieved, contributing to the proper healing of the wounded area. Moreover, nanofibers can mimic the ECM, furnishing a highly porous structural support for growing cells and subsequentially accelerating skin healing [101,102]. For instance, Amanzadi et al. [103] have fabricated a multilayer electrospun chitosan-based dressing containing Semellil Melilotus Of- 
ficinalis extract. The dressing consists of three layers: a protective polyurethane nanofibers layer, a layer of chitosan nanofibers loaded with extract, and a chitosan mat to improve the sustained release. In vivo tests on rat models revealed that the as-described textile dressing leads to an improved wound healing profile, with a wound-closure percentage of $94 \%$ after 14 days. A similar multilayer construct is proposed by Shokrollahi et al. [104]. The researchers have combined a chamomile-loaded carboxyethyl chitosan and polyvinyl alcohol nanofibrous layer (in contact with the wounded area) and a poly( $\varepsilon$-caprolactone) nanofibrous layer (strength enhancer) to create a hybrid mat for wound care. The newly developed material showed satisfactory tensile strength (8.2-16.03 MPa), antioxidant properties (6.60-38.01\%), high antibacterial efficiency, proper cell viability, and sustained chamomile release. Alternatively, Ahmadian et al. [105] have created a novel antibacterial electrospun nanofiber mat composed of ethyl cellulose, poly lactic acid, and collagen nanofibers incorporated with silver sulfadiazine. The dressing showed inhibitory properties against Bacillus $(9.71 \pm 1.15 \mathrm{~nm})$ and $E$. coli $(12.46 \pm 1.31 \mathrm{~nm})$ bacteria while improving cell proliferation and adhesion without imparting any cytotoxic effect on NIH 3T3 fibroblast cells. Thus, these mats are considered suitable for application as dressings in wounds necessitating infection control.

Another approach to designing advanced textile dressings involves the addition of micro and nanoparticles. As an example, Melamed et al. [106] have investigated copper oxide microparticle (COD)-impregnated wound dressings for the treatment of wounds in diabetic patients. The authors reported that COD significantly influenced the healing of hard-to-deal diabetic wounds, providing antibacterial effects, and directly enhancing the process. Similarly, Deokar et al. [107] have used copper oxide and zinc oxide to coat bandages, endowing them with antimicrobial properties. The authors used both water and ethanol-based syntheses, concluding that the ethanol-free bandages are safer to use (resulting in a lesser impact on embryo development) and safer to manufacture (reducing ignition risk in bulk scale production). As demonstrated by Majumder et al. [108], ZnO nanoparticles can bring synergistic properties to hybrid dressings as well. The researchers developed a biomimetic composite by grafting a hydrogel on silk fibroin fabric and functionalizing it with metal oxide NPs. The resultant wound dressing had sufficient water-vapor permeability $\left(480 \mathrm{~g} / \mathrm{m}^{2} /\right.$ day), adequate mechanical properties (tensile strength: $22.5 \pm 1.3 \mathrm{MPa}$; extension at break: $6 \pm 0.69 \mathrm{~mm}$ ), and strong antibacterial activity, being a promising material for wound management and regenerative medicine.

A different strategy is proposed by Akolpoğlu Başaran et al. [109], who have encapsulated heparin into poly(lactic-co-glycolic acid) (PLGA) nanoparticles, which were further incorporated into sericin/gelatin nanofibers during electrospinning. The researchers tested several protein ratios in the search for the optimum formulation able to ensure controlled cargo release and help skin tissue regeneration. The study obtained the most promising results for the dressing with a sericin/gelatin ratio of $1 / 2$, which presented proper fiber morphology, a high water retention degree ( 7.5 after 7 days at physiological $\mathrm{pH})$, and a low degradation degree ( $6.95 \pm 4.52 \%$ cumulative weight loss after 7 days), concluding that these constructs can be safely used for skin tissue engineering.

\subsection{Other Dressings}

Recent studies have also reported interesting results for dressings that do not fall under any category presented above. For instance, Choi and Jeon [110] have fabricated functional superabsorbent sponges made of natural polymers. The authors prepared an alginate/carboxymethyl cellulose-embedded dextran hybrid dual layer constructs via the freeze-drying method. The obtained materials could absorb large amounts of moisture (up to $1800 \%$ swelling ratio), provide morphological stability through proper tensile strength (up to $45 \mathrm{kgf} / \mathrm{cm}^{2}$ ), and uniform porosity. Encouraged by these results, the authors stated that combining this newly developed sponge with antibacterial agents could generate antimicrobial bandages for wounds necessitating the absorption of high levels of blood and body fluids. 
A different sponge-type dressing was developed by Choi et al. [111], who embedded sustained oxygen-releasing PLGA microspheres into an alginate-based hydrogel. The as-described oxygen-releasing hydrogel sponge induced neovascularization and promoted cell proliferation, thus facilitating effective wound healing. In particular, this dressing is suitable for supplying oxygen to deprived cells and tissues to enhance angiogenesis in the wounded area.

Alternatively, Kaur et al. [112] have fabricated polyvinyl alcohol (PVA)-sodium alginate membrane dressings for the topical delivery of bacteriophages (i.e., MR10 phage) and antibiotic (i.e., minocycline) to infected burn wounds. In vitro studies revealed selfadherence, antibacterial properties, and biocompatibility of the developed membrane, while in vivo tests on an MRSA-infected murine burn wound model displayed significant pathogen reduction, wound contraction, and diminished inflammation.

Antimicrobial dressings have also been prepared by incorporating beehive products as antibacterial and wound-healing agents. As an example, Tang et al. [113] have incorporated honey into an alginate/PVA-based nanofibrous membrane. The membrane dressings exhibited non-cytotoxicity, biocompatibility, and enhanced antioxidant activity, being able to control reactive oxygen species overproduction. Moreover, honey-loaded nanofibers reportedly inhibited bacterial growth, their antimicrobial activity increasing with the increase of honey content. The dressings with the highest content of honey $(20 \%)$ led to an inhibition zone diameter of $11.38 \pm 0.42 \mathrm{~mm}$ for E. coli and $13.67 \pm 1.29 \mathrm{~mm}$ for S. aureus.

Differently, Eskandarinia et al. [114] have proposed a bilayer wound dressing comprising a dense polyurethane/ethanolic extract of propolis (PUR/EEP) membrane and a polycaprolactone/gelatin (PCL/Gel) nanofibrous scaffold. The PUR/EEP layer protects the wounded area from external contamination and dehydration, whereas the PCL/Gel represents the sub-layer responsible for cell adhesion and proliferation. Overall, the bilayer structure offers potent antimicrobial activity, with diameters of inhibition zones of $5.4 \pm 0.3 \mathrm{~mm}$ against $S$. aureus, $1.9 \pm 0.4 \mathrm{~mm}$ against $E$. coli, and $1.9 \pm 0.4 \mathrm{~mm}$ against $S$. epidermidis. Furthermore, the dressing showed high hydrophilicity $\left(51.1 \pm 4.9^{\circ}\right)$, biodegradability, and biocompatibility; in vivo tests revealed a significantly improved wound closure rate and collagen deposition. Additionally, the mechanical properties (tensile strength: $5.6 \pm 0.6 \mathrm{MPa}$; elongation at break: $333.2 \pm 12.4 \%$ ) also recommend these constructs for wound management applications.

\section{Biomaterial Scaffolds}

If not treated promptly and adequately, wounds, burns, and injuries can get infected and extend on a large surface or into deeper tissues. In such cases, a wound dressing might not be sufficient for ensuring proper healing [115]. Thus, spatial reconstruction by means of biomaterial scaffolds is often implied [15]. Ideally, such constructs should be able to sustain both aesthetic and complete function tissues, imparting shape, mechanical support, and proper microarchitecture for cellular growth and reorganization to improve and stimulate the healing process [116,117].

To create performant biomaterial scaffolds, much attention has been drawn to polymerbased materials (Figure 5) that can be fabricated into diverse structures, with various configurations, degradation rates, and different drug delivery kinetics [118-121]. 


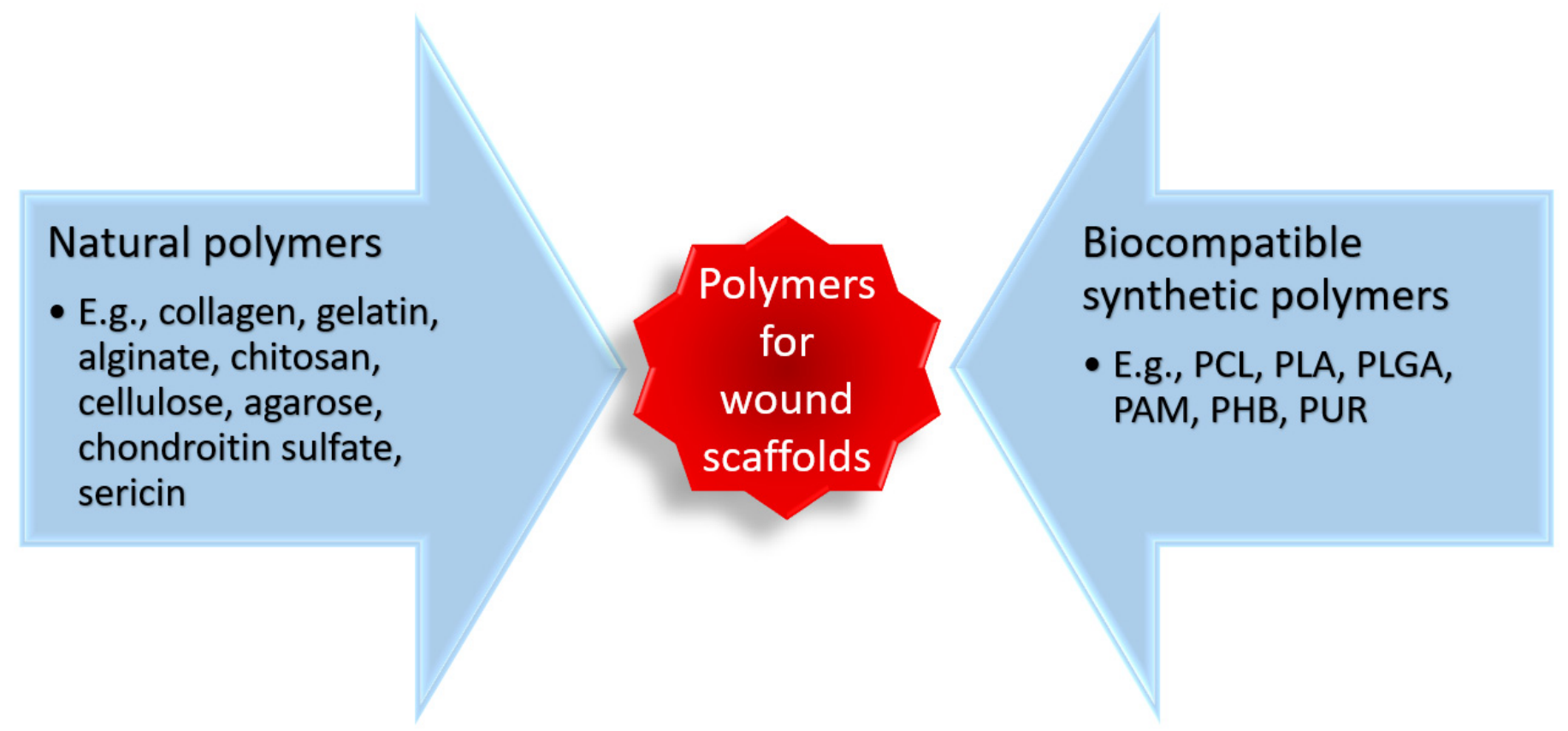

Figure 5. Classification and examples of polymers used for fabricating biomaterial scaffolds. Created based on information from [115,118,120-126]. Abbreviations: PCL-poly ( $\varepsilon$-caprolactone), PLA—polylactic acid, PLGA—poly(lactic-co-glycolic acid), PAM-polyacrylamide, PHB—poly-3hydroxybutyrate, PUR-polyurethane.

To date, collagen is the most used biopolymer for wound healing, as numerous scaffolds available on the market are based on this material $[27,118,127,128]$. Nonetheless, recent research started focusing on various other biomaterials too.

For instance, bacterial cellulose (BC) has attracted scientific interest in developing innovative scaffolds. Cherng et al. [125] have evaluated the potential of BC-based scaffolds of epithelial regeneration and wound healing in vitro and in vivo. The authors reported excellent biocompatibility in vitro, as the material was able to maintain the stemness function of cells and promote keratinocyte differentiation. Moreover, the promising results were also noted in vivo, including improved ECM deposition and controlled excessive inflammation, concluding that the tested scaffolds are suitable candidates for skin injury repair.

Chitosan is another highly researched material, especially for scaffolds able to perform drug delivery beyond their physical support role [19]. In this respect, CastilloHenriquez et al. [124] have fabricated a chitosan-based thermo-responsive scaffold that can sustain the release of Dexketoprofen trometamol for $24 \mathrm{~h}$. The developed scaffold can also reduce side effects of the drug, overcoming adherence issues and potential wound healing complications. Choudhary et al. [129] have also used this natural polysaccharide, creating chitosan-reinforced graphene-silver-polycationic peptide nanocomposites for wound healing application. The scaffolds displayed efficient antibacterial properties, unique mechanical properties, and excellent porosity, fluid absorption, and blood clotting capacity, representing viable solutions for trauma care management.

According to Napavichayanun et al. [126], interesting results were also obtained for biomaterial scaffolds made of agarose and sericin additivated with plasticizers. By the combined use of freeze-thawing and freeze-drying methods, there was obtained strong bonding between sericin and other components, resulting in a low swelling ratio and low protein release of the scaffolds, which are advantageous properties for developing controlled drug release scaffolds. In addition, the scaffolds were able to activate cell migration towards accelerating the healing process, while the plasticizers contributed to the enhancement of scaffold elasticity. 
A different example is offered by Laiva et al. [123], who have developed a collagenchondroitin sulfate scaffold functionalized with nanoparticles carrying an anti-aging gene, $\beta$-Klotho, on human adipose-derived stem cells (ADSCs). By studying this biomaterial, it was established that it ensures controlled activation of ADSC's regenerative abilities, enhances activation of transcription factor Oct-4, increases the expression of the anti-fibrotic gene TGF- $\beta 3$, controls human endothelial angiogenesis and pro-fibrotic response in dermal fibroblasts, enhances regeneration of the basement membrane, and decreases the levels of scar-associated $\alpha$-SMA protein with improved qualitative elastin matrix deposition. Overall, the identified properties highly recommend this scaffold for wound healing applications.

However, promising results were also obtained for cell-free scaffolds, as is the case in the study conducted by Gerges et al. [122]. The authors have designed a biodegradable polyurethane-based scaffold for soft tissue regeneration. The working principle was noted to be the gradual infiltration of undifferentiated mesenchymal stem cells from the periphery to the center of the scaffold, followed by the rapid formation of a functional vascular network supporting cell viability over time. Moreover, the scaffold was reported to preserve balanced physicochemical properties, with an exceptional combination between softness and resilience. Aside from polyurethane, poly ( $\varepsilon$-caprolactone) (PCL) is another promising synthetic polymer, highly researched for wound healing applications due to its availability, cost-effectiveness, biological properties, and mechanical strength [130]. Considering these advantageous features, Ahmed et al.(2021) [131] have used PCL to fabricate nanofibrous scaffolds incorporated with magnetite nanoparticles doped with different concentrations of silver ions. By making the magnetite structure more defective, silver modified the interface with the polymer, promoting the protrusion of the nanoparticles from the surface of the PCL nanofibers. Thus, the roughness and hydrophilicity of the material increased, positively impacting cell adhesion and growth. It was noted that the viability of human melanocytes, antibacterial activity against $E$. coli and S. aureus, and skin wound healing rate increased with the increase of silver in the magnetite phase of the scaffolds. The in vivo healing rate was enhanced to over $50 \%$ for the scaffold without silver ions and to over $90 \%$ for the scaffolds with the highest concentration of silver. Moreover, the samples containing the highest concentration of silver had a tensile strength of $4.42 \pm 0.25 \mathrm{MPa}$, a strain at break of $147.4 \pm 3.4 \%$, a toughness of $4.25 \pm 0.33 \mathrm{MJ} / \mathrm{m}^{3}$, and a porosity of $87.93 \pm 3.1 \%$. Therefore, the mechanical properties of the obtained composite material were fit for use in wound management and reconstructive skin therapies.

PCL was also reported as promising in combination with other polymers. For instance, Ahmed et al. (2020) [132] have created a nanofibrous blend matrix of cellulose acetate and PCL into which they incorporated various metallic nanoparticles (i.e., $\mathrm{ZnO}, \mathrm{Ag}$, and $\mathrm{CuO}$ ). The scaffolds were proven suitable candidates for wound disinfection and dressing applications, exhibiting antibacterial activity against S. aureus and E. coli. The highest inhibition zone was obtained in the case of Ag-loaded scaffolds, with diameters of around $12.3 \pm 2.2 \mathrm{~nm}$ for S. aureus and $11.2 \pm 1.5 \mathrm{~nm}$ for E. coli; however, $\mathrm{CuO}$ incorporation led to close results: $9.4 \pm 1.2 \mathrm{~nm}$ and $10.1 \pm 1.5 \mathrm{~nm}$, respectively. Alternatively, Sadeghianmaryan et al. [133] have fabricated scaffolds with homogenous and soft polyurethane nanofibers containing different amounts of PCL and nanographene oxide. All the spun scaffolds exhibited a high level of porosity $(\sim 90 \%)$, with the fiber diameter increasing as the graphene oxide concentration increased. The addition of graphene oxide to the polymer scaffolds resulted in good biocompatibility to skin fibroblast cells and increased hydrophilicity, demonstrating their potential use in skin tissue engineering.

A distinct scaffold is proposed by Guha Ray et al. [134]. The researchers modified eggshell membranes (ESM) using chitosan/PCL nanofibers towards manufacturing a bilayered scaffold. The scaffold presented a biomimetic architecture and composition, which facilitated extensive cell adhesion, migration, and proliferation. The presence of ESM led to a natural adhesion of the scaffold to the wound bed while implanted on an in vivo full-thickness wound. Compared to bare ESM, the polymer-modified scaffolds conducted 
to faster re-epithelialization and dermal regeneration with collagen deposition. Thus, it was concluded that the bilayered composite is a potential dermal substitute.

Polylactic acid (PLA) has also been utilized in various combinations to obtain innovative biomaterial scaffolds. As an example, Hajikhani et al. [135] have fabricated PVP/PLA-PEO complex nanofibers loaded with collagen and cefazolin. The authors reported that collagen doses of $10 \%$ and $20 \%$ led to significantly increased healing speed, while the samples containing $40 \%$ collagen produced a decrease in wound healing rate in mice. Moreover, the scaffolds presented antimicrobial properties, effectively inhibiting microorganisms' growth. Similarly, Fatahian et al. [136] have developed PVA/PLA nanofibrous scaffolds encapsulated with ceftriaxone (antimicrobial agent) and tranexamic acid (coagulant). The scaffolds showed more than $90 \%$ efficiency against E. coli and S. aureus, acceptable blood coagulation ability with an average absorption of $\sim 0.04 \mathrm{~nm}$, gel formation ability of about $45 \mathrm{~min}$, and successful cell proliferation.

A different approach is offered by Yu et al. [137], who have manufactured poly(lacticco-glycolic acid)/gelatin (PLGA/Gel) nanofibrous scaffolds incorporated with liraglutide (Lira) for skin tissue engineering. The scientists observed that the addition of Lira to the scaffold increased its pore size, hydrophilicity, elasticity, and degradation properties. The nanofibrous composite was evaluated on diabetic dermal wounds, showing considerably improved healing efficiency described by shortened wound closure time, increased blood vessel density, and enhanced collagen deposition and alignment. Thus, it was concluded that PLGA/Gel loaded with Lira represents a promising strategy to accelerate diabetic wound repair.

Another interesting scaffold for diabetic wounds was created by Sanhueza et al. [138], who have prepared poly-3-hydroxybutyrate (PHB) and gelatin fibrous constructs. In vitro, the scaffolds exhibited excellent fibroblasts viability and attachment after incubation for 1 , 3 , and 7 days. In vivo tests followed wound healing in diabetic rats for 21 days, leading to the observation of faster healing for gel-containing scaffolds, while the PHB-Gel treated wounds were reported to be in a late proliferative stage, with higher content of hair follicles and sweat glands and lower content in fibroblasts compared to the control wounds.

Recently, $\mathrm{pH}$-sensitive polymeric scaffolds started to gain interest in wound healing; their efficacy resides in the fact that the normal human skin $\mathrm{pH}$ is between 4 and 6 , while, in the case of an injury, it raises the physiological value [139]. In this context, Garg et al. [140] have developed a $\mathrm{pH}$-sensitive scaffold made of polyacrylamide (PAM)-grafted flax seed mucilage graft copolymeric hydrogel. The scaffold showed maximum swelling at $7.4 \mathrm{pH}$, tissue compatibility, satisfactory fibroblast growth, and sufficient collagen deposition, being considered promising materials for wound management.

\section{Challenges and Limitations}

Modern wound management has come a long way from traditional wound dressings, such as bandages and gauzes, which require a regular application, have poor adhesion properties, cannot ensure proper wound drainage, and may even cause pain upon removal [31]. Nonetheless, there is still no ideal wound dressing, neither on the market nor in research facilities, that can universally fit and heal all wound types.

The effectiveness of first-line interactive/bioactive dressings is poorly assessed as evidence is still limited to only a few clinical studies. Thus, there are needed more highquality randomized controlled trials that can bring certain confirmation on the performance of dressing products to better comprehend the state-of-the-art in the field [32].

Moreover, challenges arise in choosing the best-fitted dressing for a specific wound. Even with modern wound management options, special consideration must be given to the patient's primary disease and the physiological mechanisms of the wounds. Other dressing selection challenges may be related to legal, technical, methodological, and financial concerns that limit the possibility of conducting high-quality evidence-generating studies, hindering the translation of newly developed dressing into clinical practice [23,32]. 
In addition, clinicians and managers should be able to make more informed decisions on the costs of materials and procedures and the effects on the financial budgets of both patients and healthcare facilities. Therefore, wound management strategies should be developed in the direction of minimizing the costs while maintaining optimal clinical outcomes [141]. Better collaboration should be encouraged between the industry, clinical research, and clinical practice market segments to attain such perspectives.

\section{Conclusions and Future Perspectives}

To summarize, wounds of all sorts can occur throughout anyone's life, requiring prompt and efficient care to avoid potential complications. Thus, wound management continues to be a topic of high interest in the medical field, aiming to develop better biomaterial formulations for various dressings and scaffolds. A broad range of semipermeable films, foams, hydrogels, hydrocolloids, hydroactive dressings, alginates, and biomaterial scaffolds have been reported in the literature with different degrees of success in wound healing, while several such products have already managed to enter the market and are currently used in the clinical practice.

Nonetheless, the search for optimal wound management options concerns ongoing interdisciplinary research studies. Some of the most emerging perspectives in the field use localized nucleic acids delivery for the treatment of nonhealing chronic wounds [142], application of cold atmospheric pressure plasma treatment alongside temporary skin replacement scaffolds [143], and dosing topical formulations for wound dressings via 3D printing [144]. Moreover, the advancements encountered in the usage and regulation of stem cells paves the way for designing smart healing tools that lead to natural mimicking outcomes, where factors, such as pigmentation, epidermal appendages, vascular plexus, and subcutaneous tissues, are also restored [145].

To conclude, despite the intense research in the field, there is still room for improvement towards creating performant multifunctional dressings and scaffolds. Wound management optimization should be achieved starting from the design, materials choice, and dressing selection for specific wound types. Only through a clear understanding of the current state-of-the-art, challenges, limitations, and development perspectives, better solutions can be envisaged for effective personalized wound care.

Author Contributions: A.-G.N. and A.M.G. participated in the review writing and revision. All authors have read and agreed to the published version of the manuscript.

Funding: This research received no external funding.

Institutional Review Board Statement: Not applicable.

Informed Consent Statement: Not applicable.

Data Availability Statement: Not applicable.

Conflicts of Interest: The authors declare no conflict of interest.

\section{References}

1. Rezvani Ghomi, E.; Khalili, S.; Nouri Khorasani, S.; Esmaeely Neisiany, R.; Ramakrishna, S. Wound dressings: Current advances and future directions. J. Appl. Polym. Sci. 2019, 136, 47738. [CrossRef]

2. Bakil, S.N.A.; Kamal, H.; Abdullah, H.Z.; Idris, M.I. Sodium Alginate-Zinc Oxide Nanocomposite Film for Antibacterial Wound Healing Applications. Biointerface Res. Appl. Chem. 2020, 10, 6289-6296. [CrossRef]

3. Zhang, M.; Zhao, X. Alginate hydrogel dressings for advanced wound management. Int. J. Biol. Macromol. 2020, 162, 1414-1428. [CrossRef] [PubMed]

4. Thomas, S.; Uzun, M. 2-Testing dressings and wound management materials. In Advanced Textiles for Wound Care, 2nd ed.; Rajendran, S., Ed.; Woodhead Publishing: Cambridge, MA, USA, 2019; pp. 23-54.

5. Sajjad, W.; Khan, T.; Ul-Islam, M.; Khan, R.; Hussain, Z.; Khalid, A.; Wahid, F. Development of modified montmorillonite-bacterial cellulose nanocomposites as a novel substitute for burn skin and tissue regeneration. Carbohydr. Polym. 2019, 206, 548-556. [CrossRef] [PubMed]

6. Patil, P.S.; Evancho-Chapman, M.M.; Li, H.; Huang, H.; George, R.L.; Shriver, L.P.; Leipzig, N.D. Fluorinated methacrylamide chitosan hydrogel dressings enhance healing in an acute porcine wound model. PLoS ONE 2018, 13, e0203371. [CrossRef] 
7. El Ayadi, A.; Jay, J.W.; Prasai, A. Current Approaches Targeting the Wound Healing Phases to Attenuate Fibrosis and Scarring. Int. J. Mol. Sci. 2020, 21, 1105. [CrossRef]

8. Kaolaor, A.; Phunpee, S.; Ruktanonchai, U.R.; Suwantong, O. Effects of $\beta$-cyclodextrin complexation of curcumin and quaternization of chitosan on the properties of the blend films for use as wound dressings. J. Polym. Res. 2019, 26, 43. [CrossRef]

9. Chen, D.; Hou, Q.; Zhong, L.; Zhao, Y.; Li, M.; Fu, X. Bioactive Molecules for Skin Repair and Regeneration: Progress and Perspectives. Stem Cells Int. 2019, 2019, 6789823. [CrossRef]

10. Grimaudo, M.A.; Concheiro, A.; Alvarez-Lorenzo, C. Nanogels for regenerative medicine. J. Control. Release 2019, 313, 148-160. [CrossRef]

11. Fernández-Colino, A.; Iop, L.; Ferreira, M.S.V.; Mela, P. Fibrosis in tissue engineering and regenerative medicine: Treat or trigger? Adv. Drug Deliv. Rev. 2019, 146, 17-36. [CrossRef]

12. Andreu, V.; Mendoza, G.; Arruebo, M.; Irusta, S. Smart dressings based on nanostructured fibers containing natural origin antimicrobial, anti-inflammatory, and regenerative compounds. Materials 2015, 8, 5154-5193. [CrossRef]

13. Pickart, L.; Vasquez-Soltero, J.M.; Margolina, A. GHK peptide as a natural modulator of multiple cellular pathways in skin regeneration. BioMed Res. Int. 2015, 2015, 648108. [CrossRef] [PubMed]

14. Tiplea, R.E.; Lemnaru, G.M.; Trusca, R.D.; Holban, A.; Kaya, M.G.A.; Dragu, L.D.; Ficai, D.; Ficai, A.; Bleotu, C. Antimicrobial Films based on Chitosan, Collagen, and ZnO for Skin Tissue Regeneration. Biointerface Res. Appl. Chem. 2021, 11, 11985-11995. [CrossRef]

15. Khalili, S.; Khorasani, S.N.; Razavi, S.M.; Hashemibeni, B.; Tamayol, A. Nanofibrous scaffolds with biomimetic composition for skin regeneration. Appl. Biochem. Biotechnol. 2019, 187, 1193-1203. [CrossRef]

16. Kirby, G.T.; Mills, S.J.; Cowin, A.J.; Smith, L.E. Stem cells for cutaneous wound healing. BioMed Res. Int. 2015, $2015,285869$. [CrossRef] [PubMed]

17. Opdenakker, G.; Van Damme, J.; Vranckx, J.J. Immunomodulation as rescue for chronic atonic skin wounds. Trends Immunol. 2018, 39, 341-354. [CrossRef] [PubMed]

18. Kaushik, K.; Das, A. Endothelial progenitor cell therapy for chronic wound tissue regeneration. Cytotherapy 2019, 21, 1137-1150. [CrossRef]

19. Abirami, S.; Nagarajan, D.; Samrot, A.V.; Varsini, A.M.; Sugasini, A.; Anand, D.A. Extraction, Characterization, and Utilization of Shrimp Waste Chitin Derived Chitosan in Antimicrobial Activity, Seed Germination, Preservative, and Microparticle Formulation. Biointerface Res. Appl. Chem. 2021, 11, 8725-8739. [CrossRef]

20. Thiruvoth, F.M.; Mohapatra, D.P.; Kumar, D.; Chittoria, S.R.K.; Nandhagopal, V. Current concepts in the physiology of adult wound healing. Plast. Aesthetic Res. 2015, 2, 250-256. [CrossRef]

21. Tudoroiu, E.-E.; Dinu-Pîrvu, C.-E.; Albu Kaya, M.G.; Popa, L.; Anuța, V.; Prisada, R.M.; Ghica, M.V. An Overview of Cellulose Derivatives-Based Dressings for Wound-Healing Management. Pharmaceuticals 2021, 14, 1215. [CrossRef]

22. Tottoli, E.M.; Dorati, R.; Genta, I.; Chiesa, E.; Pisani, S.; Conti, B. Skin Wound Healing Process and New Emerging Technologies for Skin Wound Care and Regeneration. Pharmaceutics 2020, 12, 735. [CrossRef]

23. Shi, C.; Wang, C.; Liu, H.; Li, Q.; Li, R.; Zhang, Y.; Liu, Y.; Shao, Y.; Wang, J. Selection of Appropriate Wound Dressing for Various Wounds. Front. Bioeng. Biotechnol. 2020, 8, 182. [CrossRef] [PubMed]

24. Giusto, G.; Beretta, G.; Vercelli, C.; Valle, E.; Iussich, S.; Borghi, R.; Odetti, P.; Monacelli, F.; Tramuta, C.; Grego, E.; et al. Pectin-honey hydrogel: Characterization, antimicrobial activity and biocompatibility. Biomed. Mater. Eng. 2018, $29,347-356$. [CrossRef]

25. Ghanbariasad, A.; Amoozegar, F.; Rahmani, M.; Zarenezhad, E.; Osanloo, M. Impregnated nanofibrous mat with nanogel of citrus sinensis essential oil as a new type of dressing in cutaneous leishmaniasis. Biointerface Res. Appl. Chem. 2021, 11, 11066-11076. [CrossRef]

26. Nardini, M.; Perteghella, S.; Mastracci, L.; Grillo, F.; Marrubini, G.; Bari, E.; Formica, M.; Gentili, C.; Cancedda, R.; Torre, M.L. Growth Factors Delivery System for Skin Regeneration: An Advanced Wound Dressing. Pharmaceutics 2020, 12, 120. [CrossRef] [PubMed]

27. Rippa, A.L.; Kalabusheva, E.P.; Vorotelyak, E.A. Regeneration of dermis: Scarring and cells involved. Cells 2019, 8, 607. [CrossRef] [PubMed]

28. Zarrintaj, P.; Moghaddam, A.S.; Manouchehri, S.; Atoufi, Z.; Amiri, A.; Amirkhani, M.A.; Nilforoushzadeh, M.A.; Saeb, M.R.; Hamblin, M.R.; Mozafari, M. Can regenerative medicine and nanotechnology combine to heal wounds? The search for the ideal wound dressing. Nanomedicine 2017, 12, 2403-2422. [CrossRef] [PubMed]

29. Weller, C.; Weller, C.; Team, V. 4-Interactive dressings and their role in moist wound management. In Advanced Textiles for Wound Care, 2nd ed.; Rajendran, S., Ed.; Woodhead Publishing: Cambridge, MA, USA, 2019; pp. 105-134.

30. Dong, R.; Guo, B. Smart wound dressings for wound healing. Nano Today 2021, 41, 101290. [CrossRef]

31. Brumberg, V.; Astrelina, T.; Malivanova, T.; Samoilov, A. Modern Wound Dressings: Hydrogel Dressings. Biomedicines 2021, 9, 235. [CrossRef]

32. Weller, C.D.; Team, V.; Sussman, G. First-Line Interactive Wound Dressing Update: A Comprehensive Review of the Evidence. Front. Pharmacol. 2020, 11, 155. [CrossRef] 
33. Schmeel, L.C.; Koch, D.; Schmeel, F.C.; Bücheler, B.; Leitzen, C.; Mahlmann, B.; Kunze, D.; Heimann, M.; Brüser, D.; Abramian, A.-V.; et al. Hydrofilm Polyurethane Films Reduce Radiation Dermatitis Severity in Hypofractionated Whole-Breast Irradiation: An Objective, Intra-Patient Randomized Dual-Center Assessment. Polymers 2019, 11, 2112. [CrossRef]

34. Alven, S.; Aderibigbe, B.A. Hyaluronic Acid-Based Scaffolds as Potential Bioactive Wound Dressings. Polymers 2021, 13, 2102. [CrossRef]

35. Boateng, J.S.; Matthews, K.H.; Stevens, H.N.E.; Eccleston, G.M. Wound Healing Dressings and Drug Delivery Systems: A Review. J. Pharm. Sci. 2008, 97, 2892-2923. [CrossRef]

36. Denny, C.V.; Record, C. Wound Management Formulary-NHS Forth Valley. Available online: https://www.yumpu.com/en/ document/read/33366340/wound-management-formulary-nhs-forth-valley (accessed on 5 December 2021).

37. Rezaei Hosseinabadi, S.; Parsapour, A.; Nouri Khorasani, S.; Razavi, S.M.; Hashemibeni, B.; Heidari, F.; Khalili, S. Wound dressing application of castor oil- and CAPA-based polyurethane membranes. Polym. Bull. 2020, 77, 2945-2964. [CrossRef]

38. Ambrogi, V.; Pietrella, D.; Donnadio, A.; Latterini, L.; Di Michele, A.; Luffarelli, I.; Ricci, M. Biocompatible alginate silica supported silver nanoparticles composite films for wound dressing with antibiofilm activity. Mater. Sci. Eng. C 2020, 112, 110863. [CrossRef] [PubMed]

39. Rathore, H.S.; Senthilvelan, T.; Vasantharaja, R.; Abraham, L.S.; Prakash, D.; Sivagnanam, U.T.; Gupta, S. Fabrication and characterization of chitosan film impregnated ciprofloxacin drug: A comparative study. Biocatal. Agric. Biotechnol. 2019, 18, 101078. [CrossRef]

40. Hubner, P.; Donati, N.; Quines, L.K.d.M.; Tessaro, I.C.; Marcilio, N.R. Gelatin-based films containing clinoptilolite-Ag for application as wound dressing. Mater. Sci. Eng. C 2020, 107, 110215. [CrossRef]

41. Akhavan-Kharazian, N.; Izadi-Vasafi, H. Preparation and characterization of chitosan/gelatin/nanocrystalline cellulose/calcium peroxide films for potential wound dressing applications. Int. J. Biol. Macromol. 2019, 133, 881-891. [CrossRef] [PubMed]

42. Aderibigbe, B.A.; Buyana, B. Alginate in Wound Dressings. Pharmaceutics 2018, 10, 42. [CrossRef]

43. Namviriyachote, N.; Muangman, P.; Chinaroonchai, K.; Chuntrasakul, C.; Ritthidej, G.C. Polyurethane-biomacromolecule combined foam dressing containing asiaticoside: Fabrication, characterization and clinical efficacy for traumatic dermal wound treatment. Int. J. Biol. Macromol. 2020, 143, 510-520. [CrossRef]

44. Stoica, A.E.; Chircov, C.; Grumezescu, A.M. Nanomaterials for Wound Dressings: An Up-to-Date Overview. Molecules 2020, 25, 2699. [CrossRef] [PubMed]

45. Feldman, D. Polyurethane and polyurethane nanocomposites: Recent contributions to medicine. Biointerface Res. Appl. Chem 2021, 11, 8179-8189.

46. Pak, C.S.; Park, D.H.; Oh, T.S.; Lee, W.J.; Jun, Y.J.; Lee, K.A.; Oh, K.S.; Kwak, K.H.; Rhie, J.W. Comparison of the efficacy and safety of povidone-iodine foam dressing (Betafoam), hydrocellular foam dressing (Allevyn), and petrolatum gauze for split-thickness skin graft donor site dressing. Int. Wound J. 2019, 16, 379-386. [CrossRef] [PubMed]

47. Leonard, S.; McCluskey, P.; Long, S.; Butters, V.; Winter, R.; Smith, G. An evaluation of Allevyn ${ }^{\text {TM }}$ Adhesive and Non-Adhesive foam dressings. Wounds UK 2009, 5, 17-28.

48. Jung, J.-A.; Han, S.-K.; Jeong, S.-H.; Dhong, E.-S.; Park, K.-G.; Kim, W.-K. In Vitro Evaluation of Betafoam, a New Polyurethane Foam Dressing. Adv. Ski. Wound Care 2017, 30, 262-271. [CrossRef]

49. Dillon, C.K.; Iwuagwu, F. Cavi-care dressings following syndactyly correction. J. Plast. Reconstr. Aesthetic Surg. 2009, 62, e518-e519. [CrossRef]

50. Davies, P.; McCarty, S.; Hamberg, K. Silver-containing foam dressings with Safetac: A review of the scientific and clinical data. J. Wound Care 2017, 26, S1-S32. [CrossRef]

51. Marshall, C.; Shore, J.; Arber, M.; Cikalo, M.; Oladapo, T.; Peel, A.; McCool, R.; Jenks, M. Mepilex Border Sacrum and Heel Dressings for the Prevention of Pressure Ulcers: A NICE Medical Technology Guidance. Appl. Health Econ. Health Policy 2019, 17, 453-465. [CrossRef]

52. Sillmon, K.; Moran, C.; Shook, L.; Lawson, C.; Burfield, A.H. The Use of Prophylactic Foam Dressings for Prevention of Hospital-Acquired Pressure Injuries: A Systematic Review. J. Wound Ostomy Cont. Nurs. 2021, 48, 211-218. [CrossRef] [PubMed]

53. Pahlevanneshan, Z.; Deypour, M.; Kefayat, A.; Rafienia, M.; Sajkiewicz, P.; Esmaeely Neisiany, R.; Enayati, M.S. PolyurethaneNanolignin Composite Foam Coated with Propolis as a Platform for Wound Dressing: Synthesis and Characterization. Polymers 2021, 13, 3191. [CrossRef]

54. Bužarovska, A.; Dinescu, S.; Lazar, A.D.; Serban, M.; Pircalabioru, G.G.; Costache, M.; Gualandi, C.; Avérous, L. Nanocomposite foams based on flexible biobased thermoplastic polyurethane and $\mathrm{ZnO}$ nanoparticles as potential wound dressing materials. Mater. Sci. Eng. C 2019, 104, 109893. [CrossRef] [PubMed]

55. dos Santos, M.R.; Alcaraz-Espinoza, J.J.; da Costa, M.M.; de Oliveira, H.P. Usnic acid-loaded polyaniline/polyurethane foam wound dressing: Preparation and bactericidal activity. Mater. Sci. Eng. C 2018, 89, 33-40. [CrossRef] [PubMed]

56. Dutta, A.; Dutta, T.S.; Das, A.K.; Dey, P. Haemostatic action of a topical foam-based patch (VELSEAL-T) in haemophiliac patients with external bleeding. J. Haemoph. Pract. 2020, 7, 78-84. [CrossRef]

57. Hagenström, K.; Protz, K.; Glaeske, G.; Augustin, M. Wound dressings for leg ulcers in Germany: Distribution, regional variations and health care providers. Wound Med. 2018, 23, 58-63. [CrossRef]

58. Boateng, J.; Catanzano, O. Advanced Therapeutic Dressings for Effective Wound Healing-A Review. J. Pharm. Sci. 2015, 104, 3653-3680. [CrossRef] 
59. Leaper, D.; Münter, C.; Meaume, S.; Scalise, A.; Mompó, N.B.; Jakobsen, B.P.; Gottrup, F. The Use of Biatain Ag in Hard-to-Heal Venous Leg Ulcers: Meta-Analysis of Randomised Controlled Trials. PLoS ONE 2013, 8, e67083. [CrossRef]

60. Senet, P.; Bause, R.; Jørgensen, B.; Fogh, K. Clinical efficacy of a silver-releasing foam dressing in venous leg ulcer healing: A randomised controlled trial. Int. Wound J. 2014, 11, 649-655. [CrossRef] [PubMed]

61. Law, J. Cutinova ${ }^{\circledR}$ Hydro: A modern alternative to hydrocolloids. Br. J. Nurs. 2002, 11, 1279-1282. [CrossRef]

62. Flett, A.; Russell, F.; Stringfellow, S.; Cooper, P.J.; Gray, D.G.; Lawton, S. Modern wound management: Review of common products. Nurs. Resid. Care 2002, 4, 328-344. [CrossRef]

63. Ioffe, O.Y.; Kindzer, S.L.; Galiga, T.M.; Kryvopustov, M.S. Experience Of Application Of Hydroactive Bandages In The Treatment Of Diabetic Foot Syndrome. Bull. Probl. Biol. Med. 2021, 159, 72-76. [CrossRef]

64. Fulton, J.A.; Blasiole, K.N.; Cottingham, T.; Tornero, M.; Graves, M.; Smith, L.G.; Mirza, S.; Mostow, E.N. Wound dressing absorption: A comparative study. Adv. Ski. Wound Care 2012, 25, 315-320. [CrossRef]

65. Thomas, S. Hydrocolloid dressings in the management of acute wounds: A review of the literature. Int. Wound J. 2008, 5, 602-613. [CrossRef]

66. Niezgoda, J.A.; Niezgoda, J.A.; Gopalakrishnan, S. In Vitro Characterization of Pressure Redistribution Among Commercially Available Wound Dressings. Adv. Ski. Wound Care 2021, 34, 139-142. [CrossRef] [PubMed]

67. Wojcik, M.; Kazimierczak, P.; Benko, A.; Palka, K.; Vivcharenko, V.; Przekora, A. Superabsorbent curdlan-based foam dressings with typical hydrocolloids properties for highly exuding wound management. Mater. Sci. Eng. C 2021, 124, 112068. [CrossRef]

68. Collado-Boira, E.; Boldo-Roda, P.; Bernat-Adell, M.D.; Morar, K.G.; Ayora, A.F.; Medina, P.S. Effectiveness of Semiocclusive Sodium Carboxymethyl Cellulose Fibers and Hydrocolloid Dressings for Irritant Peristomal Dermatitis: A Case Series. Adv. Ski. Wound Care 2021, 34, 493-497. [CrossRef]

69. TĂNĂSescu, D. Benefits Of Hydrocolloid-Absorbent Dressings In" Diabetic Foot" Therapy. Acta Med. Transilv. 2020, 25, 22-25. [CrossRef]

70. Khalil, A.M. Interpenetrating polymeric hydrogels as favorable materials for hygienic applications. Biointerface Res. Appl. Chem. 2020, 10, 5011-5020. [CrossRef]

71. Ousey, K.; Rogers, A.A.; Rippon, M.G. Hydro-responsive wound dressings simplify T.I.M.E. wound management framework. Br. J. Community Nurs. 2016, 21, S39-S49. [CrossRef]

72. Rashaan, Z.M.; Krijnen, P.; van den Akker- van Marle, M.E.; van Baar, M.E.; Vloemans, A.F.P.; Dokter, J.; Tempelman, F.R.H.; van der Vlies, C.H.; Breederveld, R.S. Clinical effectiveness, quality of life and cost-effectiveness of Flaminal ${ }^{\circledR}$ versus Flamazine ${ }^{\circledR}$ in the treatment of partial thickness burns: Study protocol for a randomized controlled trial. Trials 2016, 17, 122. [CrossRef]

73. Edwards, J. Hydrogels and their potential uses in burn wound management. Br. J. Nurs. 2010, 19, S12-S16. [CrossRef]

74. Cooke, M.; Chadwick, P.; Haycocks, S.; Rippon, M.; Simm, S.U.E. Enabling wound healing and preventing limb amputation: A cost-benefit case study of Hydro-Responsive Wound Dressings. Wounds UK 2017, 13, 80-91.

75. Jones, A.; Vaughan, D. Hydrogel dressings in the management of a variety of wound types: A review. J. Orthop. Nurs. 2005, 9, S1-S11. [CrossRef]

76. Irmukhametova, G.S.; Mun, G.A.; Khutoryanskiy, V.V. Hydrogel Dressings. In Therapeutic Dressings and Wound Healing Applications; John Wiley and Sons Ltd.: Chichester, UK, 2020; pp. 185-207.

77. Nešović, K.; Janković, A.; Radetić, T.; Vukašinović-Sekulić, M.; Kojić, V.; Živković, L.; Perić-Grujić, A.; Rhee, K.Y.; MiškovićStanković, V. Chitosan-based hydrogel wound dressings with electrochemically incorporated silver nanoparticles-In vitro study. Eur. Polym. J. 2019, 121, 109257. [CrossRef]

78. Diniz, F.R.; Maia, R.C.A.P.; Rannier Andrade, L.; Andrade, L.N.; Vinicius Chaud, M.; da Silva, C.F.; Corrêa, C.B.; de Albuquerque Junior, R.L.C.; Pereira da Costa, L.; Shin, S.R.; et al. Silver Nanoparticles-Composing Alginate/Gelatine Hydrogel Improves Wound Healing In Vivo. Nanomaterials 2020, 10, 390. [CrossRef] [PubMed]

79. Gupta, A.; Briffa, S.M.; Swingler, S.; Gibson, H.; Kannappan, V.; Adamus, G.; Kowalczuk, M.; Martin, C.; Radecka, I. Synthesis of Silver Nanoparticles Using Curcumin-Cyclodextrins Loaded into Bacterial Cellulose-Based Hydrogels for Wound Dressing Applications. Biomacromolecules 2020, 21, 1802-1811. [CrossRef]

80. Khorasani, M.T.; Joorabloo, A.; Moghaddam, A.; Shamsi, H.; MansooriMoghadam, Z. Incorporation of ZnO nanoparticles into heparinised polyvinyl alcohol/chitosan hydrogels for wound dressing application. Int. J. Biol. Macromol. 2018, 114, 1203-1215. [CrossRef]

81. Raafat, A.I.; El-Sawy, N.M.; Badawy, N.A.; Mousa, E.A.; Mohamed, A.M. Radiation fabrication of Xanthan-based wound dressing hydrogels embedded ZnO nanoparticles: In vitro evaluation. Int. J. Biol. Macromol. 2018, 118, 1892-1902. [CrossRef]

82. Kudinov, V.A.; Artyushev, R.I.; Zurina, I.M.; Lapshin, R.D.; Snopova, L.B.; Mukhina, I.V.; Grinakovskaya, O.S.; Saburina, I.N. Antimicrobial and Regenerative Effects of Placental Multipotent Mesenchymal Stromal Cell Secretome-Based Chitosan Gel on Infected Burns in Rats. Pharmaceuticals 2021, 14, 1263. [CrossRef]

83. Fahmy, A.; Khafagy, R.M.; Elhaes, H.; Ibrahim, M.A. Molecular properties of polyvinyl alcohol/sodium alginate composite. Biointerface Res. Appl. Chem. 2020, 10, 4734-4739. [CrossRef]

84. Barbu, A.; Neamtu, B.; Zăhan, M.; Iancu, G.M.; Bacila, C.; Mireșan, V. Current Trends in Advanced Alginate-Based Wound Dressings for Chronic Wounds. J. Pers. Med. 2021, 11, 890. [CrossRef]

85. Varaprasad, K.; Jayaramudu, T.; Kanikireddy, V.; Toro, C.; Sadiku, E.R. Alginate-based composite materials for wound dressing application:A mini review. Carbohydr. Polym. 2020, 236, 116025. [CrossRef] [PubMed] 
86. Deng, Y.; Yang, N.; Okoro, O.V.; Shavandi, A.; Nie, L. Alginate-Based Composite and Its Biomedical Applications. In Properties and Applications of Alginates; IntechOpen: London, UK, 2021.

87. McCarthy, S.; Dvorakova, V.; O'Sullivan, P.; Bourke, J.F. Anaphylaxis caused by alginate dressing. Contact Dermat. 2018, 79, 396-397. [CrossRef] [PubMed]

88. Paul, W.; Sharma, C.P. Alginates: Wound dressings. In Encyclopedia of Biomedical Polymers and Polymeric Biomaterials; CRC Press: New York, NY, USA, 2015; pp. 134-146.

89. Qin, Y. The characterization of alginate wound dressings with different fiber and textile structures. J. Appl. Polym. Sci. 2006, 100, 2516-2520. [CrossRef]

90. Zhao, W.-Y.; Fang, Q.-Q.; Wang, X.-F.; Wang, X.-W.; Zhang, T.; Shi, B.-H.; Zheng, B.; Zhang, D.-D.; Hu, Y.-Y.; Ma, L.; et al. Chitosan-calcium alginate dressing promotes wound healing: A preliminary study. Wound Repair Regen. 2020, 28, 326-337. [CrossRef]

91. Wang, M.; Yang, Y.; Yuan, K.; Yang, S.; Tang, T. Dual-functional hybrid quaternized chitosan/Mg/alginate dressing with antibacterial and angiogenic potential for diabetic wound healing. J. Orthop. Transl. 2021, 30, 6-15. [CrossRef] [PubMed]

92. Liang, L.; Hou, T.; Ouyang, Q.; Xie, L.; Zhong, S.; Li, P.; Li, S.; Li, C. Antimicrobial sodium alginate dressing immobilized with polydopamine-silver composite nanospheres. Compos. Part B Eng. 2020, 188, 107877. [CrossRef]

93. Azam, M.; Dikici, S.; Roman, S.; Mehmood, A.; Chaudhry, A.A.; Rehman, I.U.; MacNeil, S.; Yar, M. Addition of 2-deoxy-d-ribose to clinically used alginate dressings stimulates angiogenesis and accelerates wound healing in diabetic rats. J. Biomater. Appl. 2019, 34, 463-475. [CrossRef]

94. Emam, H.E. Antimicrobial cellulosic textiles based on organic compounds. 3 Biotech 2019, 9, 29. [CrossRef] [PubMed]

95. Celebioglu, A.; Topuz, F.; Yildiz, Z.I.; Uyar, T. One-step green synthesis of antibacterial silver nanoparticles embedded in electrospun cyclodextrin nanofibers. Carbohydr. Polym. 2019, 207, 471-479. [CrossRef] [PubMed]

96. Cova, T.F.; Murtinho, D.; Pais, A.A.; Valente, A.J. Combining cellulose and cyclodextrins: Fascinating designs for materials and pharmaceutics. Front. Chem. 2018, 6, 271. [CrossRef]

97. Leclercq, L. Smart medical textiles based on cyclodextrins for curative or preventive patient care. In Active Coatings for Smart Textiles; Elsevier: Amsterdam, The Netherlands, 2016; pp. 391-427.

98. Liu, Y.; Li, T.; Han, Y.; Li, F.; Liu, Y. Recent development of electrospun wound dressing. Curr. Opin. Biomed. Eng. 2021, 17, 100247. [CrossRef]

99. Dong, Y.; Zheng, Y.; Zhang, K.; Yao, Y.; Wang, L.; Li, X.; Yu, J.; Ding, B. Electrospun Nanofibrous Materials for Wound Healing. Adv. Fiber Mater. 2020, 2, 212-227. [CrossRef]

100. Jeckson, T.A.; Neo, Y.P.; Sisinthy, S.P.; Gorain, B. Delivery of Therapeutics from Layer-by-Layer Electrospun Nanofiber Matrix for Wound Healing: An Update. J. Pharm. Sci. 2021, 110, 635-653. [CrossRef]

101. Hermosilla, J.; Pastene-Navarrete, E.; Acevedo, F. Electrospun Fibers Loaded with Natural Bioactive Compounds as a Biomedical System for Skin Burn Treatment. A Review. Pharmaceutics 2021, 13, 2054. [CrossRef]

102. Wang, F.; Hu, S.; Jia, Q.; Zhang, L. Advances in electrospinning of natural biomaterials for wound dressing. J. Nanomater. 2020, 2020, 8719859. [CrossRef]

103. Amanzadi, B.; Mirzaei, E.; Hassanzadeh, G.; Mahdaviani, P.; Boroumand, S.; Abdollahi, M.; Abdolghaffari, A.H.; Majidi, R.F. Chitosan-based layered nanofibers loaded with herbal extract as wound-dressing materials on wound model studies. Biointerface Res. Appl. Chem. 2019, 9, 3979-3986.

104. Shokrollahi, M.; Bahrami, S.H.; Nazarpak, M.H.; Solouk, A. Multilayer nanofibrous patch comprising chamomile loaded carboxyethyl chitosan/poly(vinyl alcohol) and polycaprolactone as a potential wound dressing. Int. J. Biol. Macromol. 2020, 147, 547-559. [CrossRef]

105. Ahmadian, S.; Ghorbani, M.; Mahmoodzadeh, F. Silver sulfadiazine-loaded electrospun ethyl cellulose/polylactic acid/collagen nanofibrous mats with antibacterial properties for wound healing. Int. J. Biol. Macromol. 2020, 162, 1555-1565. [CrossRef]

106. Melamed, E.; Rovitsky, A.; Roth, T.; Assa, L.; Borkow, G. Stimulation of Healing of Non-Infected Stagnated Diabetic Wounds by Copper Oxide-Impregnated Wound Dressings. Medicina 2021, 57, 1129. [CrossRef]

107. Deokar, A.R.; Perelshtein, I.; Saibene, M.; Perkas, N.; Mantecca, P.; Nitzan, Y.; Gedanken, A. Antibacterial and In Vivo Studies of a Green, One-Pot Preparation of Copper/Zinc Oxide Nanoparticle-Coated Bandages. Membranes 2021, 11, 462. [CrossRef]

108. Majumder, S.; Ranjan Dahiya, U.; Yadav, S.; Sharma, P.; Ghosh, D.; Rao, G.K.; Rawat, V.; Kumar, G.; Kumar, A.; Srivastava, C.M. Zinc Oxide Nanoparticles Functionalized on Hydrogel Grafted Silk Fibroin Fabrics as Efficient Composite Dressing. Biomolecules 2020, 10, 710. [CrossRef]

109. Akolpoğlu Başaran, D.D.; Gündüz, U.; Tezcaner, A.; Keskin, D. Topical delivery of heparin from PLGA nanoparticles entrapped in nanofibers of sericin/gelatin scaffolds for wound healing. Int. J. Pharm. 2021, 597, 120207. [CrossRef]

110. Choi, J.; Jeon, H. Manufacture and Characterization of Alginate-CMC-Dextran Hybrid Double Layer Superabsorbent Scaffolds. Appl. Sci. 2021, 11, 11573. [CrossRef]

111. Choi, J.; Hong, G.; Kwon, T.; Lim, J.O. Fabrication of Oxygen Releasing Scaffold by Embedding H2O2-PLGA Microspheres into Alginate-Based Hydrogel Sponge and Its Application for Wound Healing. Appl. Sci. 2018, 8, 1492. [CrossRef]

112. Kaur, P.; Gondil, V.S.; Chhibber, S. A novel wound dressing consisting of PVA-SA hybrid hydrogel membrane for topical delivery of bacteriophages and antibiotics. Int. J. Pharm. 2019, 572, 118779. [CrossRef] 
113. Tang, Y.; Lan, X.; Liang, C.; Zhong, Z.; Xie, R.; Zhou, Y.; Miao, X.; Wang, H.; Wang, W. Honey loaded alginate/PVA nanofibrous membrane as potential bioactive wound dressing. Carbohydr. Polym. 2019, 219, 113-120. [CrossRef]

114. Eskandarinia, A.; Kefayat, A.; Agheb, M.; Rafienia, M.; Amini Baghbadorani, M.; Navid, S.; Ebrahimpour, K.; Khodabakhshi, D.; Ghahremani, F. A Novel Bilayer Wound Dressing Composed of a Dense Polyurethane/Propolis Membrane and a Biodegradable Polycaprolactone/Gelatin Nanofibrous Scaffold. Sci. Rep. 2020, 10, 3063. [CrossRef]

115. Iga, C.; Agata, T.; Marcin, Ł.; Natalia, F.; Justyna, K.-L. Ciprofloxacin-Modified Degradable Hybrid Polyurethane-Polylactide Porous Scaffolds Developed for Potential Use as an Antibacterial Scaffold for Regeneration of Skin. Polymers 2020, $12,171$. [CrossRef] [PubMed]

116. Wang, K.; Ho, C.-C.; Zhang, C.; Wang, B. A Review on the 3D Printing of Functional Structures for Medical Phantoms and Regenerated Tissue and Organ Applications. Engineering 2017, 3, 653-662. [CrossRef]

117. Shah, G.; Costello, B.J. Soft tissue regeneration incorporating 3-dimensional biomimetic scaffolds. Oral Maxillofac. Surg. Clin. 2017, 29, 9-18. [CrossRef]

118. Shpichka, A.; Butnaru, D.; Bezrukov, E.A.; Sukhanov, R.B.; Atala, A.; Burdukovskii, V.; Zhang, Y.; Timashev, P. Skin tissue regeneration for burn injury. Stem Cell Res. Ther. 2019, 10, 94. [CrossRef] [PubMed]

119. Feldman, D.S. Biomaterial enhanced regeneration design research for skin and load bearing applications. J. Funct. Biomater. 2019, 10, 10. [CrossRef]

120. Pina, S.; Ribeiro, V.P.; Marques, C.F.; Maia, F.R.; Silva, T.H.; Reis, R.L.; Oliveira, J.M. Scaffolding strategies for tissue engineering and regenerative medicine applications. Materials 2019, 12, 1824. [CrossRef]

121. Selvan, N.K.; Shanmugarajan, T.; Uppuluri, V.N.V.A. Hydrogel based scaffolding polymeric biomaterials: Approaches towards skin tissue regeneration. J. Drug Deliv. Sci. Technol. 2020, 55, 101456. [CrossRef]

122. Gerges, I.; Tamplenizza, M.; Martello, F.; Recordati, C.; Martelli, C.; Ottobrini, L.; Tamplenizza, M.; Guelcher, S.A.; Tocchio, A.; Lenardi, C. Exploring the potential of polyurethane-based soft foam as cell-free scaffold for soft tissue regeneration. Acta Biomater. 2018, 73, 141-153. [CrossRef]

123. Laiva, A.L.; O’Brien, F.J.; Keogh, M.B. Anti-Aging $\beta$-Klotho Gene-Activated Scaffold Promotes Rejuvenative Wound Healing Response in Human Adipose-Derived Stem Cells. Pharmaceuticals 2021, 14, 1168. [CrossRef] [PubMed]

124. Castillo-Henríquez, L.; Sanabria-Espinoza, P.; Murillo-Castillo, B.; Montes de Oca-Vásquez, G.; Batista-Menezes, D.; CalvoGuzmán, B.; Ramírez-Arguedas, N.; Vega-Baudrit, J. Topical Chitosan-Based Thermo-Responsive Scaffold Provides Dexketoprofen Trometamol Controlled Release for $24 \mathrm{~h}$ Use. Pharmaceutics 2021, 13, 2100. [CrossRef] [PubMed]

125. Cherng, J.-H.; Chou, S.-C.; Chen, C.-L.; Wang, Y.-W.; Chang, S.-J.; Fan, G.-Y.; Leung, F.-S.; Meng, E. Bacterial Cellulose as a Potential Bio-Scaffold for Effective Re-Epithelialization Therapy. Pharmaceutics 2021, 13, 1592. [CrossRef]

126. Napavichayanun, S.; Pienpinijtham, P.; Reddy, N.; Aramwit, P. Superior Technique for the Production of Agarose Dressing Containing Sericin and Its Wound Healing Property. Polymers 2021, 13, 3370. [CrossRef] [PubMed]

127. Pallaske, F.; Pallaske, A.; Herklotz, K.; Boese-Landgraf, J. The significance of collagen dressings in wound management: A review. J. Wound Care 2018, 27, 692-702. [CrossRef]

128. El Blidi, O.; El Omari, N.; Balahbib, A.; Ghchime, R.; El Menyiy, N.; Ibrahimi, A.; Ben Kaddour, K.; Bouyahya, A.; Chokairi, O.; Barkiyou, M. Extraction Methods, Characterization and Biomedical Applications of Collagen: A Review. Biointerface Res. Appl. Chem. 2021, 11, 13587-13613. [CrossRef]

129. Choudhary, P.; Ramalingam, B.; Das, S.K. Fabrication of Chitosan-Reinforced Multifunctional Graphene Nanocomposite as Antibacterial Scaffolds for Hemorrhage Control and Wound-Healing Application. ACS Biomater. Sci. Eng. 2020, 6, 5911-5929. [CrossRef]

130. Raina, N.; Pahwa, R.; Khosla, J.K.; Gupta, P.N.; Gupta, M. Polycaprolactone-based materials in wound healing applications. Polym. Bull. 2021. [CrossRef]

131. Ahmed, M.K.; Zayed, M.A.; El-dek, S.I.; Hady, M.A.; El Sherbiny, D.H.; Uskoković, V. Nanofibrous E-polycaprolactone scaffolds containing Ag-doped magnetite nanoparticles: Physicochemical characterization and biological testing for wound dressing applications in vitro and in vivo. Bioact. Mater. 2021, 6, 2070-2088. [CrossRef] [PubMed]

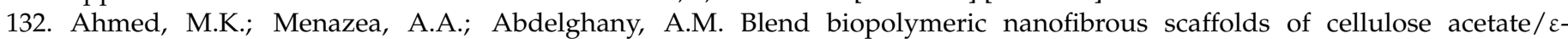
polycaprolactone containing metallic nanoparticles prepared by laser ablation for wound disinfection applications. Int. J. Biol. Macromol. 2020, 155, 636-644. [CrossRef] [PubMed]

133. Sadeghianmaryan, A.; Karimi, Y.; Naghieh, S.; Alizadeh Sardroud, H.; Gorji, M.; Chen, X. Electrospinning of Scaffolds from the Polycaprolactone/Polyurethane Composite with Graphene Oxide for Skin Tissue Engineering. Appl. Biochem. Biotechnol. 2020, 191, 567-578. [CrossRef]

134. Guha Ray, P.; Pal, P.; Srivas, P.K.; Basak, P.; Roy, S.; Dhara, S. Surface Modification of Eggshell Membrane with Electrospun Chitosan/Polycaprolactone Nanofibers for Enhanced Dermal Wound Healing. ACS Appl. Bio Mater. 2018, 1, 985-998. [CrossRef]

135. Hajikhani, M.; Emam-Djomeh, Z.; Askari, G. Fabrication and characterization of mucoadhesive bioplastic patch via coaxial polylactic acid (PLA) based electrospun nanofibers with antimicrobial and wound healing application. Int. J. Biol. Macromol. 2021, 172, 143-153. [CrossRef]

136. Fatahian, R.; Mirjalili, M.; Khajavi, R.; Rahimi, M.K.; Nasirizadeh, N. A novel hemostat and antibacterial nanofibrous scaffold based on poly(vinyl alcohol)/poly(lactic acid). J. Bioact. Compat. Polym. 2020, 35, 189-202. [CrossRef] 
137. Yu, M.; Huang, J.; Zhu, T.; Lu, J.; Liu, J.; Li, X.; Yan, X.; Liu, F. Liraglutide-loaded PLGA/gelatin electrospun nanofibrous mats promote angiogenesis to accelerate diabetic wound healing via the modulation of miR-29b-3p. Biomater. Sci. 2020, 8, 4225-4238. [CrossRef]

138. Sanhueza, C.; Hermosilla, J.; Bugallo-Casal, A.; Da Silva-Candal, A.; Taboada, C.; Millán, R.; Concheiro, A.; Alvarez-Lorenzo, C.; Acevedo, F. One-step electrospun scaffold of dual-sized gelatin/poly-3-hydroxybutyrate nano/microfibers for skin regeneration in diabetic wound. Mater. Sci. Eng. C 2021, 119, 111602. [CrossRef] [PubMed]

139. Hendi, A.; Hassan, M.U.; Elsherif, M.; Alqattan, B.; Park, S.; Yetisen, A.K.; Butt, H. Healthcare applications of pH-Sensitive hydrogel-based devices: A review. Int. J. Nanomed. 2020, 15, 3887. [CrossRef] [PubMed]

140. Garg, S.; Bal, T.; Panpalia, S.G.; Rajora, A.D.; Ghosh, B.D. Preparation and characterization of microwave irradiated pH-sensitive polyacrylamide grafted flax seed mucilage graft copolymeric hydrogel (PFLSM-g-PAM-cl-MBA) and its evaluation as effective polymeric scaffold. Sustain. Chem. Pharm. 2021, 22, 100479. [CrossRef]

141. Al-Gharibi, K.A.; Sharstha, S.; Al-Faras, M.A. Cost-Effectiveness of Wound Care: A concept analysis. Sultan Qaboos Univ Med J 2018, 18, e433-e439. [CrossRef]

142. Berger, A.G.; Chou, J.J.; Hammond, P.T. Approaches to Modulate the Chronic Wound Environment Using Localized Nucleic Acid Delivery. Adv. Wound Care 2021, 10, 503-528. [CrossRef]

143. Emmert, S.; Pantermehl, S.; Foth, A.; Waletzko-Hellwig, J.; Hellwig, G.; Bader, R.; Illner, S.; Grabow, N.; Bekeschus, S.; Weltmann, K.-D.; et al. Combining Biocompatible and Biodegradable Scaffolds and Cold Atmospheric Plasma for Chronic Wound Regeneration. Int. J. Mol. Sci. 2021, 22, 9199. [CrossRef] [PubMed]

144. de Oliveira, R.S.; Fantaus, S.S.; Guillot, A.J.; Melero, A.; Beck, R.C. 3D-Printed Products for Topical Skin Applications: From Personalized Dressings to Drug Delivery. Pharmaceutics 2021, 13, 1946. [CrossRef]

145. Boyce, S.T.; Lalley, A.L. Tissue engineering of skin and regenerative medicine for wound care. Burn. Trauma 2018, 6, 4. [CrossRef] 